\title{
Creditor Rights, Enforcement and Bank Loans
}

\author{
Kee-Hong Bae and Vidhan K. Goyal
}

Current draft: August 9, 2007.

\begin{abstract}
We examine if differences in legal protection affect loan amounts, maturity and interest rate spreads on loans to borrowers in 48 countries. Results show that banks respond to poor enforceability of contracts by reducing loan quantities, shortening loan maturities and increasing loan spreads. These effects are both statistically significant and economically large. Average loan sizes will be $\$ 53$ million larger, maturities will be 2.5 years longer, and spreads will be 67 basis points lower, if a borrower moves from a country with the weakest protection of property rights to a country with the strongest protection of property rights, all else equal. While stronger creditor rights reduce spreads, they do not seem to matter for loan sizes and loan maturities. Overall, we show that variations in enforceability of contracts matter a great deal more for how loan are structured and how they are priced.
\end{abstract}

JEL classification: D23, G21, G32, K42

Keywords: property rights, creditor rights, law, enforcement, investor protection, loan amounts, maturity, loan spreads, syndicate structure

Kee-Hong Bae is with the Department of Finance, Queen's School of Business, Queen's University, Kingston, Ontario, Canada. Phone: 1-613-533-3275, E-mail: kbae@business.queensu.ca.

Vidhan K. Goyal is with the Department of Finance, Hong Kong University of Science and Technology, Clear Water Bay, Kowloon, Hong Kong. Phone: +852 2358-7678, E-mail: goyal@ust.hk.

Acknowledgments: We thank Adam Ashcraft, Kalok Chan, Stijn Claessens, Florencio Lopez-de-Silanes, Vojislav Maksimovic, Darius Miller, Kwangwoo Park, Marco Pagano, Gordon Phillips, Rene Stulz, K.C. John Wei; seminar participants at the International Monetary Fund, University of Maryland, Korea University, Queen's University; participants at the 2004 Georgia Tech International Finance Conference, the 2004 Financial Intermediation Research Society Conference, the 2005 Asia-Pacific Corporate Governance conference, the 2005 CIFRA International Conference on Financial Development and Governance; and especially an anonymous referee and the associate editor for helpful comments. Vidhan Goyal thanks HKUST research grant \#DAG02/03.BM22 for research support. We alone are responsible for any errors. (C) 2007 by Kee-Hong Bae and Vidhan K. Goyal. All rights reserved. 


\section{Introduction}

The extent to which property rights are protected in a country is an important consideration in determining what loans are offered to firms, how these loans are structured, and how they are priced. Property rights protection affects a lender's incentives to monitor and its ability to recontract. Declining credit quality often results in lenders raising interest rates, demanding more collateral, shortening loan maturity, and further restricting future activities. This recontracting is costly when property rights are poorly enforced. Poor enforcement lowers recovery rates and increases the time spent in repossessing collateral following default. ${ }^{1}$

In addition to enforcement, what is also important for lenders is the legal rights that they have in reorganization and liquidation procedures. Differences in creditor rights matter for loan contracting because laws determine who controls the insolvency process and who has rights to the property of a bankrupt firm. How do differences in creditor rights and contract enforceability affect the amounts banks lend to firms, maturity of the loans they make, and the interest rate spreads they charge? Are laws and enforcement equally important for loan contracting process? Bhattacharya and Daouk $(2002,2005)$ argue that it is the enforcement, not the existence of laws that matters. Qian and Strahan (2007) suggest that it is the creditor rights, not the protection of property rights that matter.

The recent case of Asia Pulp and Power (APP), controlled by Indonesia's Widjaja family, illustrates the difficulty of recontracting in weak property rights environments. In 2003, the company owed almost US\$14 billion to foreign banks, fund managers, and various credit agencies. The foreign banks that lent to APP found it hard to reschedule debt payments. The media reported that the Indonesian courts have not been very helpful in enforcing loan contracts and that the family had snubbed their foreign lenders, often not turning up for scheduled meetings to discuss debt repayments. Citing other examples from Indonesia, Bloomberg (April 28, 2003) states that "the lack of a credible legal infrastructure makes enforcing rights in Indonesia's courts almost

\footnotetext{
${ }^{1}$ The local legal tradition and enforceability of contract is what matters in loan contracting. The location of the lender matters less. Most borrowers file for bankruptcy in their home country.
} 
impossible." Indonesia scores high on creditor rights but low on property rights protection.

This paper examines the effects of creditor rights and property rights protection on loan contracts. Banks are expected to charge higher interest rate spreads when they are lending to firms operating in countries with weak creditor rights and poor enforcement. However, as risks increase, instead of increasing interest rates, banks would ration some borrowers (Stiglitz and Weiss, 1981). Thus loan quantities will shrink as legal risks increase. Loan maturities will also respond to higher legal risks. Diamond (2004) suggests that in legal systems with expensive or ineffective contract enforcement, more short-term debt will be issued. Short-maturity debt allows lenders to more frequently review their lending decisions and restrict borrower flexibility to increase the riskiness of assets. We examine all three aspects of loan contracting - loan quantity, loan maturity and loan spreads. In relating these loan variables to laws and enforcement measures, we control for other factors that are likely to affect loan contracting, including loan syndicate structure and composition, agency participation in loans, loan purpose and loan type, priority structure, borrower risk characteristics, country sovereign risk, measures of financial and economic development, borrower industry, year and country-effects. We establish our results on a fairly large sample of loans (over 63,000 loans worth US\$13 trillion) to firms in 48 countries during 1994-2003.

Results show that better enforceability of contracts increases loan sizes, lengthens loan maturities, and reduces loan spreads. These effects are both statistically significant and economically large. Average loan amounts will increase by about $\$ 57$ million if a borrower moves from a country with the weakest protection of property rights in the sample to a country with the strongest protection of property rights, all else equal. Similarly loan maturities will increase by 2.5 years and loan spreads will decline by 67 basis points in moving from a country with the weakest protection of property rights to strongest protection of property rights.

Loan spreads also respond to variation in creditor rights. A smaller decline in spreads of 41 basis points, nonetheless significant, is predicted if a borrower moves from a country with that scores the worst on creditor rights to a country that scores the best, all else equal. The effect of creditor rights on loan amounts and loan maturity is weak, often statistically insignificant. 
Finally, we examine loans offered to firms around the East Asian financial crisis of 1997-98. Aggregate loan volumes dropped substantially in the affected countries during the financial crisis that started sometime in July 1997 and lasted at least until the third quarter of 1998. We find that banks further responded by significantly reducing loan maturities and increasing loan spreads to borrowers in East Asian countries during the crisis period. Importantly, we find that the increase in loan spreads during the crisis is relatively larger for firms in countries with poor enforceability of contracts and weak creditor rights. These results further imply that laws and their enforcement have substantial micro-level effects on borrower's cost of loan finance.

This research is broadly related to previous work which shows that secure property rights are associated with higher values of stock markets (La Porta et al., 1997); a higher number of listed firms (La Porta et al., 1997); higher valuation of listed firms relative to their assets (Claessens et al., 2002; La Porta et al., 2002b); greater use of external finance (La Porta et al., 1997, 1998, 2002a); and greater investments from external funds (Rajan and Zingales, 1998; Demirgüç-Kunt and Maksimovic, 1998). ${ }^{2}$ More evidence is provided in Besley (1995); Mauro (1995); Levine (1999); Levine et al. (2000); Acemoglu et al. (2001). Loan contracting appears to be an important channel for law and enforcement to affect external finance, investment and firm growth rates.

Other research has examined how legal institutions affect costs of external financing. Hail and Luez (2006) examine how legal institutions affect cost of equity (estimated from share prices and analysts' forecasts). Miller and Puthenpurackal (2002) examine how investor protection affects premiums on Yankee bonds. We provide consistent evidence using a sample of bank loans. To gauge the relative important of bank loans in comparison to equity and public debt financing, we plot the issuances of loans, bonds and equity for 49 countries over roughly the same period. Figure 1 shows that

\footnotetext{
${ }^{2}$ Cross-country research also attempts to establish the causality from financial development to country growth rates. Rajan and Zingales (1998) show that in countries with well-developed financial systems, industries with greater external financing requirements grow relatively faster. Demirgüç-Kunt and Maksimovic $(1998,1999)$ show that better investor protection increases the likelihood that a firm will make greater use of external financing and that it will be less constrained in making productive investments.
} 
banks are fairly important in allocating credit to private firms in countries around the world. ${ }^{3}$

In other related work, Laeven and Majnoni (2005) examine the effect of judicial protection of property rights on country-level interest rate spreads. Jappelli et al. (2005) and Pinheiro and Cabral (1999) find that even within a country, regional variation in judicial efficiency affects the amount of lending and the terms at which loans are made. Desai et al. (2004) examine the determinants of capital structure of foreign affiliates of U.S. multinational firms and find that when affiliates operate in weak creditor rights countries, they borrow less externally. More closely related are papers that examine how creditor rights affect syndicate structure and syndicate composition. Esty and Megginson (2003) examine how creditor rights protection and law enforcement affect the size and concentration of lending syndicates using a sample of internationally syndicated project loans. Esty (2006) examines how creditor rights protection and law enforcement affect the willingness of foreign banks to lend to domestic projects.

In a recent paper, Qian and Strahan (2007) focus on creditor rights and find that stronger legal rights result in longer maturity loans and lower spreads. Instead, we examine both creditor rights and enforceability of contracts and show that it is the enforceability, not merely the existence of rights, that matters for loan contracting. We use time-varying measures of creditor rights and property rights and are able to control for unobservable country heterogeneity using country-effects. ${ }^{4}$ Results show that controlling for these country effects is important. In addition, we show that poor enforceability of contracts results in smaller and more concentrated syndicates, suggesting that monitoring and recontracting issues are relatively more important when property rights are poorly protected. Overall, the results in this paper and those in previous studies substantially enhance our understanding of how laws and enforcement affect loan contracts.

The remainder of this paper is organized as follows. Section II describes the loan data and the various loan samples considered in the study. It also discusses measures

\footnotetext{
${ }^{3}$ The figure plots data on the relative importance of different forms of external financing in 49 countries. Bond and equity issuance data are from Thomson Financial and the loan data are from the Loan Pricing Corporation.

${ }^{4}$ Pooled OLS estimates are likely to be biased and inefficient in the presence of unobservable country effects (see Woolridge, 2002).
} 
of creditor rights and property rights protection. Section III provides a discussion of factors that affect international bank lending contracts. Section IV presents the descriptive statistics on loan and borrower characteristics. Section V presents our main empirical results and Section VI discusses robustness issues. Section VII examines loan contracts around the East Asian crisis of 1997-98. Section VIII concludes the paper.

\section{Data}

\section{A. Description of the loan database}

Information on bank loans is from the Dealscan database compiled by the Loan Pricing Corporation (LPC). We begin by including all loan tranches in the LPC database from 1994 to 2003, where the borrower is from one of the 49 countries in the La Porta et al. (1998) database. The sample starts in 1994 since LPC's coverage of loans in the pre1994 period is almost non-existent for countries other than the US; LPC's efforts in the early 1990s were primarily focused on the US loan market.

We analyze these loan transactions by placing minimum restrictions other than requiring non-missing loan spreads, maturity, and loan sizes. ${ }^{5}$ This results in a sample of 63,158 loan tranches to about 22,000 borrowers from 48 countries over the 1994-2003 period. ${ }^{6}$ These loans aggregate to about US\$13 trillion in constant dollars.

We also examine two subsets of this sample. The first subset includes loans matched to the Worldscope database. Worldscope has accounting information required for constructing measures of borrower risk characteristics. The matching is done based on firm names in the two databases and much of it is done manually. The Worldscope matched sample consists of 17,791 loans to 4,407 borrowers in 38 countries. The total loan amounts equal to about US\$5 trillion in constant dollars. ${ }^{7}$

\footnotetext{
${ }^{5}$ The missing loan maturity can sometimes be estimated by taking the difference between the loan origination date and the loan maturity date. We make this estimation whenever possible.

${ }^{6}$ Borrowers occasionally enter into more than one loan tranche on the same date. Instead of aggregating multiple tranches into a single loan deal, we use tranches as the unit of analysis. Results are robust to the random exclusion of all except one tranche in a deal.

${ }^{7}$ We compare the matched LPC borrowers to typical Worldscope firms in their country. The matched borrowers are almost twice as large as a typical Worldscope firm. They also are significantly more
} 
The second subset includes only US\$ loans which are priced as spreads over London Interbank Offered Rate (LIBOR). This is done to ensure comparability in terms of currency and benchmark used for pricing loans. This sample is 12,271 loans to 3,283 borrowers in 37 countries. The total loans amounts equal to about US\$ 4 trillion in constant dollars. ${ }^{8}$

Appendix I provides number of loans and aggregate loan amounts for both US borrower and non-US borrowers across these different samples. Almost 70 percent of these loan tranches are to the US firms. We therefore analyze non-US borrowers separately. Appendix II gives a breakdown on the number of loans, median loan spreads, loan sizes and loan maturities and borrower characteristics by country. These borrower characteristics are described in Section III.

\section{B. Measuring property rights protection}

To measure the extent to which a country respects private property rights, we rely on three country risk variables that measure corruption, the risk of expropriation of private property, and the risk that contracts may be repudiated. Section VI reports tests which consider alternative measures of property rights.

The three indices measure the extent to which a country's legal systems and institutions enforce all contracts, including government contracts. The primary series are obtained from the International Country Risk Guide (ICRG). The annual values obtained from ICRG are means calculated from all 12 monthly values for each variable. Corruption index ranges from 0 to 6 while the repudiation of contracts and risk of expropriation are scales ranging from 0 to 10 . Higher values indicate better ratings, i.e. less risk. The corruption index is rescaled so that the range for each index is between zero and ten with low values indicating less respect for private property. ICRG descriptions are as follows:

profitable compared to a typical Worldscope firm. Strahan (1999) reaches similar conclusions for US borrowers in LPC.

${ }^{8}$ The Dealscan database includes a variable called "Base Rate and Margin" which includes information on whether the loan is priced as spread over LIBOR or if some other benchmark is used. Overall, about 86 percent of sample loans are priced as spreads over LIBOR. The percentage of LIBOR-based loans as a fraction of all loans exceeds 80 percent for most countries (including countries in Asia). 
Corruption: According to ICRG, the corruption index is "an assessment of corruption within the political system. Such corruption is a threat to foreign investment for several reasons: it distorts the economic and financial environment and it reduces the efficiency of government and business by enabling people to assume positions of power through patronage rather than ability." Lower scores indicate that "high government officials are likely to demand special payments" and that illegal payments are generally expected throughout lower levels of government in the forms of bribes "connected with import or export licenses, exchange controls, tax assessment, police protection, or loans."

Risk of repudiation: This indicator "addresses the possibility that foreign businesses contractors and consultants face the risk of a modification in a contract taking the form of repudiation, postponement, or scaling down, due to an income drop, budget cutbacks, and indigenization priorities." Lower scores signify a greater likelihood that a country will modify or repudiate a contract with a foreign business.

Risk of expropriation of private investment: This variable measures the risk of "outright confiscation and forced nationalization" of property. Lower ratings imply that expropriation of private foreign investment is a likely event.

While ICRG continues to report data on corruption until 2003, the annual series for the other two indices are not available beyond 1997. We therefore construct the property rights index by keeping the risk of contract repudiation and risk of expropriation constant in the post-1997 period. This allows us to use as much time-variation in the index as possible. We examine how loan spreads respond to these three indices separately in Table $\mathrm{V}$ but for the most part, the three indices are combined into an additive index of property rights protection (see Morck et al., 2000).

\section{Measuring creditor rights}

Lenders care about recovery rates in the event of a default. The recovery rates, the ability to repossess collateral and to reorganize debtors, depend largely on the legal rights that creditors have in reorganization and liquidation procedures. Bankruptcy laws define who controls the insolvency process and who has rights to the property of a bankrupt firm and with what priority. 
Djankov et al. (2007) measure legal rights of creditors against defaulting debtors in different jurisdictions by constructing a "creditor rights" index. The index is constructed as of January of every year between 1978 and 2003 for a sample of 129 countries. It measures four powers of secured lenders in bankruptcy. The first measure is whether secured creditors are able to seize their collateral once reorganization petition is approved. In other words, there is no 'automatic stay' on assets imposed by the court. The second measure is whether there are restrictions such as creditor consent when a borrower files for reorganization, as opposed to debtors seeking unilateral protection from creditors' claims by filing for rehabilitation. The third is if secured creditors are paid first out of the proceeds of liquidating a bankrupt firm or if thirdparty claims take priority. The final measure is whether creditors or an administrator are responsible for running the business during reorganization, rather than having the debtor continue to run the business. Djankov, McLeish, and Shleifer add a value of one to the index if a country's law and regulations provide each of these powers to secured lenders. These scores are aggregated into a creditor rights index which varies from 0 (poor creditor rights) to 4 (strong creditor rights). They find that laws change slowly as there is a high degree of persistence in creditor rights index with differences persisting over the 25-year period. ${ }^{9}$

\section{Factors affecting lending contracts across countries}

Variation in laws and enforcement affects borrower incentives to expropriate and to increase the riskiness of assets. It affects default probabilities, recoveries in default and consequently a lender's incentives to monitor and its ability to re-contract. These differences in legal risk across countries will sometimes deter lending. At other times, loans would be for smaller amounts, or will have shorter maturities, or higher spreads. In countries with weak rights and poor enforcement, relatively higher quality borrowers will qualify for bank loans; in other countries their will be greater variation in borrower quality. The types of industries and thus the kind of assets to which banks

\footnotetext{
${ }^{9}$ La Porta et al. (1998) measure of creditor rights is available for a single cross-section of countries (year 1995). The two are highly correlated but Djankov, McLeish, and Shleifer improves on the La Porta, Lopez-de Silanes, Shleifer, and Vishny measure by coding insolvency procedures differently and by providing a time series of this variable.
} 
lend to might differ across countries. This suggests that banks respond to differences in legal risk in many different ways. In this section, we discuss several mechanisms that previous literature has identified as important in addressing legal risks and suggest control variables that we use later in the analysis.

Syndicate structure: Esty and Megginson (2003) argue that legal risks affect syndicate size and concentration. ${ }^{10}$ Smaller and more concentrated syndicates have better monitoring incentives and greater recontracting ability. Sufi (2007) argues that concentrated lending aligns incentives required to provide due-diligence and monitoring by an informed lender when information asymmetries are large. Due-diligence, monitoring and recontracting ability would be relatively more important in countries with weak creditor rights and poor enforcement. However, if the objective of banks is to structure syndicates to deter strategic default, higher legal risks will result in larger and less concentrated syndicates (see Esty and Megginson, 2003; Qian and Strahan, 2007). Syndicate size reflects the number of banks lending in a syndicate. Syndicate concentration is a Herfindahl index calculated using each syndicate member's share in the loan. We also use an alternative measure of concentration, which is the share of the largest lender in a loan syndicate.

Syndicate composition: foreign lenders: Esty (2006) argues that legal risks affect syndicate composition. According to Esty, creditor rights and legal enforcement issues are more important for foreign banks than they are for local banks. The literature, however, is divided on this issue. Some commentators argue that host governments are less likely to expropriate their own banks. If this is true, then foreign lenders might deliberately bring in local lenders as syndicate members. Others argue that syndicates composed of foreign lenders provide a stronger deterrent against expropriation.

The effect of foreign participation on spreads is similarly unclear. Esty (2006) argues that foreign participation will increase spreads if foreign lenders receive additional compensation for providing greater deterrence against sovereign intervention. On the other hand, foreign banks might prefer to ration credit than to increase loan spreads (to avoid adverse selection problems as in Stiglitz and Weiss (1981)). Another possibility is

\footnotetext{
${ }^{10}$ Most lending in the sample is in the form of syndicated bank loans. Syndicated loans are made by a group of banks that jointly extend a loan to a specific borrower. Esty (2001) provides a detailed description of the syndication process.
} 
that foreign bank participation is associated with greater competitive pressures during the bidding process, which leads to lower spreads.

Agency participation: Lenders can mitigate legal risks by co-lending with multilateral or bi-lateral agencies such as International Finance Corporation (IFC), country development banks, central banks, and western Export-Import banks. According to Esty and Megginson (2003), agency lenders help deter strategic defaults, resolve complicated legal issues, and protect contractual agreements from sovereign influence. Thus, when agency lenders are a part of loan syndicates, loan amounts would be larger, loan maturities longer, and spreads will be smaller. Involvement of agency lenders, on the other hand, might also indicate that these loans have high ex-ante risk. Agency participation indicator variable equals one if one or more of these agencies participate in the syndicate, and zero otherwise.

Borrower risk characteristics: Heterogeneity in borrower risk would also affect the structure of lending contracts. Differences in (a) firm size, (b) profitability, (c) leverage, (d) the collateral value of assets, and (e) growth opportunities could have important effects on contracting costs. ${ }^{11}$

(a) Firm size: Larger firms are typically more diversified, are mature, better known and have lower default risk. They have also been around longer which means they have probably acquired reputation in debt markets. This suggests that large firms should have fewer contracting problems. Firm size is measured as the natural log of total assets in constant US\$.

(b) Profitability: Profitable firms have lower default risk and less severe moral hazard problems. Incentives to expropriate assets and to increase the risk of business are greater when firms are less profitable. Thus, profitable firms are expected to have lower contracting costs. Profitability is measured by the ratio of operating income over assets.

\footnotetext{
${ }^{11}$ Previous research uses borrower ratings to control for borrower credit risk. However, many borrowers are not rated and LPC does not always report ratings. As indicated earlier, requiring a rating for the borrower at issuance substantially reduced the sample. We therefore focus on accounting proxies for credit quality. We have also analyzed a sample of loans for which LPC reported borrower credit ratings. These results show that in no case does the addition of rating dummy materially affects the coefficient on other variables in the regression. Moreover, the coefficient estimate of the rating dummy itself is never statistically significant.
} 
(c) Leverage: Levered firms have greater agency costs of debt since they are more likely to underinvest when a disproportional amount of benefits accrue to the lenders (Myers, 1977). Highly leveraged firms have greater incentives to increase the riskiness of assets. However, higher leverage could also proxy for the fact that the firm has acquired a reputation in debt markets, which reduces contracting problems. Leverage is measured by the ratio of total debt to book assets.

(d) Tangibility: Tangible assets are easier to collateralize and suffer a smaller loss of value when firms go into distress. Thus, tangibility reduces the costs of financial distress. In addition, tangibility makes it difficult for shareholders to substitute high-risk assets for low-risk ones reducing agency costs of debt. The low information asymmetry associated with tangible assets makes it easier for lenders to monitor borrowers. Higher tangibility therefore implies lower contracting costs. Tangibility is measured by the ratio of fixed assets to total assets.

(e) Growth: Growth firms lose more of their value when they go into distress. Several agency theories predict that contracting costs are higher for growth firms. For example, the underinvestment problem is more severe for growth firms (see Myers, 1977). In addition, as growth options increase, asset substitution problems become severe. In high growth firms, it is easier for stockholders to increase project risk and it is harder for lenders to detect such changes. Adverse selection costs are greater in growth firms because managers find it more difficult to communicate credible information about growth opportunities to lenders than information about assets already in place. A countervailing argument is that growth firms have access to valuable projects that generate a stream of quasi-rents. Such firms are less likely to engage in risky investment strategies or to engage in other activities to expropriate creditors. Growth opportunities are measured as the ratio of market value of assets (assets less book equity plus market value of common equity) to book assets.

Loan purpose and priority structure: Lenders could mitigate risks by directing lending to specific purposes. In countries with weak protection for property rights, lenders might prefer to loan for the purposes of investment in physical assets which constrain a firm's ability to change the risk of its assets. In countries with stronger protection, 
they might make loans for making acquisitions or provide a general line of credit as a backup for commercial paper facility. ${ }^{12}$ In addition, in high legal risk environments, lenders might lend on a secured basis or require that bank loans be senior.

Industry: Lenders could also change the mix of industries to which they lend to in different countries. Variation in creditor rights and enforceability of contracts will affect whether industries that face greater product market competition or those with mostly intangible assets receive bank loans. We therefore include 75 industries dummies representing SIC codes at the two-digit level. In addition, we explicitly examine loan quantities, maturities and spreads to financial borrowers since international banks could address poor creditor rights in the target country by channeling funds through local financial institutions.

Sovereign risk rating: Sovereign risk ratings, a measure of country risk, affect ratings assigned to borrowers of the same nationality. According to Cantor and Packer (1997), rating agencies seldom assign a credit rating to a company that is higher than that of the borrower's home country. Existing research shows that sovereign ratings provide additional information about country risk not contained in other macro-variables. The ratings data are obtained from Standard and Poor and are converted to a numerical score with higher numbers reflecting worse ratings. We use the log transformation of sovereign credit rating variable in the regression specification.

Level of economic development: Bank lending will also be affected by differences in the degree of economic development. Political stability of a country is often a function of its GDP per capita. Importantly, La Porta et al. (1998) argue that laws and their enforcement vary as a function of GDP per capita. Creditor rights are stronger in poorer countries while richer countries have a higher quality of law enforcement. The annual values of GDP per capita for countries in our sample are from the World Development Indicators database (obtained from the World Bank website). The values for Taiwan are from the Taiwan Economic Journal database. In Section VI, we examine other macroeconomic variables that might affect lending in a country.

\footnotetext{
${ }^{12}$ Esty and Megginson (2003) and Esty (2006) examine project finance loans. Project companies are mostly private, stand-alone entities. They extensively use high leverage and operate primarily natural resources and infrastructure projects. In the Worldscope matched samples, very few loans are project finance loans. We classify these loans together with other loans. Keeping them as a separate category or including them together with loans for the purpose of financing investment in assets has no appreciable effect on any of our findings. Esty (2004) calls for more research on project finance transactions.
} 


\section{Summary statistics}

Table I presents summary statistics for property rights index, creditor rights, loan terms, syndicate structure, loan purpose and borrower characteristics. We first compute median values of the variables for each country in the sample and then provide summary statistics of these medians. While we present these statistics for the sample of 17,791 loans to Worldscope matched borrowers, the inferences about how these characteristics vary as a function of creditor rights and enforceability across countries are qualitatively similar on the other two samples.

Median of median country loan spread is about 83 basis points. The mean is 105.3 and the standard deviation is 69.52 suggesting a large variation in country median loan spreads. Median of median loan maturity is about 3.5 years again with substantial cross-country variation. Median of median loan size is about US\$100 million. ${ }^{13} \mathrm{~A}$ median of $4 \%$ of loans are secured. Most loans are classified as senior. Only a small fraction of loans include agency lenders in their syndicates.

The median of median syndicate size is eight lenders. Syndicate sizes vary substantially across countries. The $10^{\text {th }}$ percentile is four banks while the $90^{\text {th }}$ percentile is 15.5 banks. Foreign banks constitute a majority of these syndicates. Median syndicate has six foreign lenders. As a fraction of the overall syndicate size, foreign banks represent a median of $78 \%$ of the overall syndicate. Foreign banks provide the largest share of the median loan. The median syndicate is dispersed with the biggest lender contributing a median of $14.3 \%$ of the loan tranche. The Herfindahl index is about $12 \%$. Thus, most lending is by large and dispersed syndicates.

About $44 \%$ of loans are for working capital or general corporate purposes. The second most frequent loan purpose is refinancing (about 20\%). Loans for the purposes of acquisitions/recapitalization appear about 12 percent of the time. Loans for capital expenditures or for financing assets, loans for commercial paper backup, and other loans appear less frequently.

\footnotetext{
${ }^{13}$ Both loan size and firm size are converted to millions of year 2000 US $\$$ using a deflator based on the Consumer Price Index (CPI) values for respective countries. Year 2000 is the base year. The data on CPI is from the World Development Indicators database except the values for Taiwan which are obtained from the Taiwan Economic Journal database.
} 
The borrowers in the Worldscope matched LPC firms are large. The median of median asset value is about $\$ 3.3$ billion (in constant US\$). Median of median leverage ratio is 0.32 . Borrowers are profitable (the median of median profitability is 0.06 ). The median tangibility ratio is 0.39 and the median market-to-book assets ratio is 1.1.

Tables II and III examine how loan terms, syndicate structure, loan purpose and borrower characteristics vary as a function of property rights and creditor rights. The property rights index is an aggregation of the three indices - corruption, risk of contract repudiation, and risk of expropriation. Creditors rights index is from Djankov et al. (2007). Before presenting these results in a table, we plot median loan sizes, median loan maturities, and median loan spreads against property rights index and creditor rights. Figures 2(a) and 2(b) plot median loan sizes. Figures 2(c) and 2(d) plot median loan maturities and Figures 2(e) and 2(f) plot median loan spreads. These plots show that loan spreads decline as laws and enforcement improve. Loan sizes increase as property rights get stronger but decline with improvements in creditor rights. Median loan maturities are flat when plotted against property rights and increase as creditor rights become stronger.

Table II presents median values of loan and firm characteristics in countries grouped according to the strength or property rights. Countries with weak protection of property rights are in the bottom-third of property rights index. Countries with medium protection are in the middle-third and countries with strong protection are in the top-third of the property rights index. Although the descriptive statistics show that creditor rights vary directly with property rights, the correlation between two indices is only about 0.25 .

Loan spreads are lower in countries with strong property rights protection. They are about 150 basis points for countries in the bottom third in terms of property rights protection, declining to 75 basis points for countries in the middle third and to about 49 basis points for countries in the top third. Median loan maturities and loan sizes also differ across countries with different enforcement regimes. Compared to loan maturities for countries with weak and medium property rights, loan maturities are a year longer for countries with strong property rights protection. Loan sizes also increase slightly as property rights get stronger. Lenders more frequently lend on a secured basis in countries with weak property rights protection. Participation of agency lenders 
is greater in countries that have weak property rights countries, consistent with the argument that co-lending with agency lenders is more valuable when legal risks are high.

Syndicate sizes are smaller and syndicates more concentrated in countries with weak property rights. Furthermore, foreign bank participation in syndicates is highest in countries with weak property rights protection although this relation is not monotonic. Syndicates in strong property rights countries also have more foreign participation. Countries in the middle have less foreign lenders. Loans to firms in weak property rights are more often for the purpose of capital expenditure or for financing specific investments. Fewer loans in such countries are for the purposes of acquisition or for recapitalization.

Although firm sizes are larger in countries with strong enforceability of contracts, other borrower characteristics exhibit a tendency on the part of lenders to lend to relatively higher quality firms in countries with poor enforcement of contracts. Borrowers in weak property rights countries have higher profitability, more tangible assets and higher market-to-book ratio compared to borrowers in countries with strong protection of property rights.

Table III presents the descriptive statistics for loan and borrower characteristics for countries classified by creditor rights. Loan spreads are higher and loan maturities longer in countries with weak creditor rights. Median loan sizes, however, decline in countries with strong creditor rights. A higher fraction of loans are secured and more loans have agency lenders in their syndicates in countries with weak creditor rights. The syndicate structure does not seem to show any clear pattern with creditor rights. Syndicate sizes are larger and less concentrated in countries with medium creditor rights. The borrowers in weak creditor rights countries have higher asset tangibility, higher profitability and higher market-to-book ratio. Other differences are less dramatic. 


\section{Results}

The summary statistics presented in the previous section show significant differences in loan and borrower characteristics across countries. The important question is whether the variation in creditor rights and property rights protection causes differences in loan quantities, loan maturities and loan spreads, other things being equal. To show that contract enforceability and creditor rights matter for lending contracts, it is important to control for borrower risk characteristics, priority structure, syndicate composition and structure, loan purpose, country risk measures, industry effects, time-period effects, and country effects.

The samples we examine pool a large number of loans to borrowers from a crosssection of countries during the 1994-2003 period. There are a potentially large number of unmeasured country variables that could matter for loan contracting. These unobservable country-level differences should be accounted for in the estimations.

We start with a discussion of the econometric issues related to treatment of country effects and then present the key results.

\section{A. Estimation method}

In random effect regressions, country level effects are simply parameterized as additional random disturbances. The advantage of country random effect specification is that it adjusts standard errors to reflect the cross-correlation between observations due to common country components instead of treating firms in a given country as independent observations. Random effect estimates are therefore more efficient than pooled OLS estimates with clustered standard errors. ${ }^{14}$

To test if random effects are indeed needed, we perform the Lagrange Multiplier (LM) test suggested by Breusch and Pagan (1980) for each of the models in Table IV. The random effects specification is strongly supported in the data in each of these es-

\footnotetext{
${ }^{14}$ See Petersen (2007) for a discussion of the importance of correcting for clustering of standard errors in panel estimations. Petersen also provides the Stata code for implementing the two-way clustering of standard errors which can be downloaded here: http: / www . kellogg. northwestern. edu / faculty/petersen/htm/papers/se/se_programming.htm.
} 
timations. The tests uniformly reject the null hypothesis that errors are independent within countries.

An econometric issue with random effects is that it assumes country effects are uncorrelated with the regressors. This is unlikely to be the case and a formal test is presented below. The question is how critical this assumption is for the inferences we obtain. An alternative to random effect estimation is to rely on fixed effect estimation where country effects are allowed to be correlated with the regressors. However, if country level variables such as the property rights index and creditor rights index show relatively little within variance (the variance over time) and significantly larger between variance (the variance across countries), "the fixed effects will soak up most of the explanatory power of these slowly changing variables" Beck (2001, page 285). ${ }^{15}$

We test the key assumption that country effects are uncorrelated with the regressors using a Hausman test. The null hypothesis is that the extra orthogonality conditions imposed by the random effect estimators are valid. The test requires fitting both models - the random effects and the fixed effects - and then comparing their common estimates in a probabilistic sense. If both random effects and fixed effects generate consistent point estimates of the slope parameters, they will not differ substantially. If the orthogonality assumption is violated, the random effect estimates will significantly differ from their fixed effects counterparts.

The coefficient estimates from both fixed effects and random effects estimations for loan size, loan maturity and loan spread regressions (corresponding to Columns (1) to (3) of Table IV) are presented in Appendix Table III. Although the test rejects the null hypothesis, a comparison of the coefficient estimates from the two models shows that they do not differ meaningfully. The one major difference is the effect of creditor rights, which is insignificant in fixed effect estimation. Other coefficient estimates and their significance levels are similar in the two estimation methods.

\footnotetext{
${ }^{15}$ See Baltagi (2001), Woolridge (2002), Hsiao (2003), and Plümper and Troeger (2007) for a discussion of issues with fixed effects estimations.
} 


\section{B. Random effect estimates}

Table IV presents the coefficient estimates from random effects regression of loan size, loan maturity and loan spreads. As described in Section II, we examine three different loan samples. Columns (1) to (3) present results for the sample of all loans. Columns (4) to (6) examine loans to borrowers matched to firms in Worldscope. Finally, Columns (7) to (9) examine a subset of these loans denominated in US\$ and priced as spreads over LIBOR.

The dependent variables are the natural log of loan tranche amount (in columns labeled as 'Size'), the natural log of loan maturity (in columns labeled as 'Maturity') and the natural logarithm of all-in interest spreads (in columns labeled as 'Spread'). The interest rate spreads are spreads over LIBOR or a similar benchmark (including any annual fee and other upfront fees prorated over the life of the loan). ${ }^{16}$

The key variables of interest on the right hand side are the two indices of creditor rights and property rights. The regressions include agency participation indicator, financial borrower indicator, term loan indicator, loan purpose indicators, the natural $\log$ of sovereign credit rating, the natural log of GDP per capita, firm size, profitability, leverage, tangibility, and the market-to-book assets ratio. The spread regressions additionally include syndicate composition, other non-price loan terms such as log of maturity, log of loan size, security and seniority indicator. The explanatory variables are lagged so that they are at least in the information set of the lenders. All of the regressions include annual year dummies to control for differences in loan quantities, maturities and spreads that reflect changing market conditions. Regressions in Columns (4) to (7) additionally include industry dummies.

The results show that loan amounts increase, loan maturities get longer and loan spreads decline with improvement in property rights. The smaller loan sizes in countries where contracts are poorly enforced suggests that lenders impose quantity restrictions in response to uncertain legal environments. The smaller loan maturities in countries where contracts are poorly enforced suggests that banks shorten loan maturity to review their lending decisions more frequently and restrict borrower flexibility

\footnotetext{
${ }^{16} \mathrm{LPC}$ does not provide spreads and fees separately so it is not possible to adjust fees in a more sophisticated way.
} 
to expropriate creditors (Diamond, 1991, 1993). ${ }^{17}$ The higher loan spreads in countries where contracts are poorly enforced suggests that lenders require additional compensation when there is greater risk of enforceability of contracts. The coefficients on creditor rights in the loan spread regressions are negative and statistically significant suggesting that loan spreads also respond to creditor rights. Loan sizes and loan maturities do not show consistent relations with creditor rights.

Agency participation increases loan sizes, results in longer maturities and lowers loan spreads. Loans to financial borrowers are smaller, have shorter maturities, and lower spreads. Term loans are smaller, have longer maturities and higher spreads. Loan for acquisition purposes have higher spreads while loans backing up commercial paper facilities have lower spreads. The effect of sovereign credit rating on loan size is not robust but what is clear is that worse ratings result in shorter loan maturities and higher loan spreads suggesting that sovereign credit rating matters for loan maturity and loan spreads in the country.

Several borrower characteristic variables have the predicted sign. Larger firms borrow larger amounts while highly levered firms borrow smaller amounts. Loan sizes increase with tangibility of assets and the market-to-book ratio. Loan maturities increase with profitability but decline with tangibility and the market-to-book assets ratio. Both firm size and profitability are negatively related to spreads. More leveraged firms pay higher spreads, suggesting default risks are important. However, tangibility of assets and market-to-book ratios are not significantly related to loan spreads.

We find the effects of syndicate structure and composition to be sensitive to the sample under consideration. In the sample that includes all loans, loans with larger syndicates have lower spreads, and loans with greater foreign participation have lower spreads. Some of these effects reverse when smaller samples are considered. We have experimented with replacing syndicate size with the share of the biggest lender and with Herfindahl index of syndicate concentration. We have also experimented with alternative measure of foreign lender participation based on the dollar share of foreign banks in a syndicate. The conclusions from these results are unchanged.

\footnotetext{
${ }^{17}$ Demirgüç-Kunt and Maksimovic (1999) also show that debt maturities are longer in countries with strong legal rules and strong enforcement.
} 
The loan spread regressions include loan maturity and loan size as pre-determined variables. Results are similar if predicted loan sizes and predicted loan maturities are used instead. Loan maturity is positively related to loan spreads consistent with longer maturity loans being riskier and higher spreads being charged on long-term loans. The coefficient on loan size is negative consistent with larger loans being made to better borrowers. Secured loans have higher spreads while senior loans have lower spreads.

In summary, the results regarding the effect of property rights protection indicate that banks charge smaller spreads, offer longer maturity loans and increase loan sizes when borrowers are operating in countries with stronger protection of property rights. The estimated coefficients from Column (7) suggest that, with all other variables set at their mean values, predicted loan sizes would increase from $\$ 84$ million at the minimum value of property rights protection to about $\$ 137$ million at the maximum value of property rights protection. Loan maturities would increase from 1.7 years to 4.2 years as a borrower moves from a country with poor protection of property rights to the strongest protection of property rights. Finally, spreads decline from 118 basis points at the minimum value of property rights protection (Colombia in 1998) to 51 basis points at the maximum value of property rights protection (Finland, Germany, Netherlands and Norway in various years). Consistent with these findings, Miller and Puthenpurackal (2002) find similar evidence of an economically significant decline in bond spreads in the Yankee bond market.

Focusing on the creditor rights index, the results in Column (9) of Table IV show that predicted loan spreads range from 55 basis points when creditor rights are strongest to 96 basis points when creditor rights are weakest, all else equal.

Figures 3(a) and 3(b) plot the average predicted loan sizes against property rights index and creditor rights index, respectively (with all other variables in Column (7) of Table IV set at their mean). Figures 3(c) and 3(d) plot the average predicted loan maturities against property rights index and creditor rights, respectively (with all other variables in Column (8) of Table IV set at their mean). Finally, Figures 3(e) and 3(d) plot the average predicted loan spreads against property rights index and creditor rights index when all other variables in in Column (9) of Table IV are set at their mean values. Loan spreads decline substantially over the entire range of property rights index 
values. Loan spreads also decline over the entire range of creditor rights but drop is less dramatic.

Table $\mathrm{V}$ provides additional evidence on the components of property rights and creditor rights matter more for loan contracts. We only present the loan spread regressions to save space. Loan size and loan maturity regressions yield conclusions that are similar.

Columns (1) to (3) of Table V examine the three property rights indices separately - i.e. the corruption index, the risk of contract repudiation and risk of expropriation. Results show that loan spreads are lower in countries with higher levels of corruption, greater risks of expropriation, and higher risk of contract repudiation.

Column (4) includes an interaction term between the additive index of property rights and the creditor rights index to examine the joint effects of rules and enforcement. The interaction term is negative and statistically significant at the one percent level. Thus, having strong creditor rights in addition to strong property rights results in an additional reduction in spreads.

Columns (5) to (8) examine the four components of creditor rights separately. The question is whether all of the laws are equally effective or are some laws more important than others. The four creditor rights indices include (1) restrictions on entering reorganization (2) absence of automatic stay on assets, (3) respect for the priority of secured creditor, and (4) mandatory removal of management in bankruptcy. Results show that all four laws result in smaller spreads.

\section{Robustness}

\section{A. Enforcement measures}

This section examines if results hold when alternative measures of property rights indices are examined. The following alternatives are considered.

1. Rule of law: This is an index of the law and order tradition of the country and is scaled from 0 to 10 with higher scores for countries with more tradition for law 
and order. The rule-of-law "reflects the degree to which the citizens of a country are willing to accept the established institutions to make and implement laws and adjudicate disputes." Higher scores indicate: "sound political institutions, a strong court system, and provisions for an orderly succession of power." Lower scores indicate "depending on physical force or illegal means to settle scores." Upon changes in government, new leaders may be less likely to accept the obligations of the previous regime. The annual values of this variable from 1994 to 2003 are obtained from International Country Risk Guide.

2. Efficiency of the judicial system: This is an assessment of the "efficiency and integrity of the legal environment as it affects business, particularly foreign firms" produced by the country risk rating agency, International Country Risk (ICR). We obtained the measure from La Porta et al. (1998) which is an average from 1980 to 1993 and has a scale of 0 to 10 , with lower scores implying lower efficiency levels.

3. Property rights index from the Index of Economic Freedom: This measure of property rights is from the Index of Economic Freedom compiled by the Heritage Foundation/Wall Street Journal since 1995. The annual values are obtained from the Heritage Foundation website.

4. Enforcement: This is an index of the effectiveness of legal system in enforcing contracts. The variable is the average of the efficiency of the judicial system, rule of law, risk of expropriation and contract repudiation and is obtained from La Porta et al. (1998). ${ }^{18}$ Higher values indicate better enforcement.

5. Property rights index from Knack and Keefer (1995): Knack and Keefer constructed a 50-point "property rights index" by converting corruption, rule of law and bureaucratic quality to 10-point scales (by multiplying them with 5/3) and summing them with contract repudiation and expropriation risk. The individual series used in constructing the Knack and Keefer property rights index are obtained from the International Country Risk Guide.

6. Contract enforcement time and contract enforcement cost: Contract enforcement time and contract enforcement costs are proxies for the efficiency of courts, which is

\footnotetext{
${ }^{18}$ Results are robust to updating rule of law, risk of expropriation and contract repudiation to annual values to 1997 we obtained from International Country Risk Guide.
} 
the main institution enforcing the legal system. These variables report the number of days it takes to enforce a commercial contract and the costs (as a share of income) incurred in the enforcement process and are taken from the World Bank "Doing Business" database (Release 2004)

Table VI presents results from country random effects estimations that use these alternative proxies for enforcement of contracts in place of property rights index described in Section II. We report results from regressions relating loan spreads to these alternative proxies of property rights. Results from loan size and loan maturity regressions are similar.

Column (1) of Table VI reports results from including the rule of law variable as a proxy for property rights protection. Consistent with earlier results, the coefficient on rule of law is negative and statistically significant implying that loan spreads are lower when a country has a better law and order tradition. Column (2) employs the efficiency of judicial system as a measure of property rights protection. The coefficient is negative and significant at the one percent level. ${ }^{19}$ In Column (3), we employ the property rights index from the Index of Economic Freedom compiled by the Heritage Foundation. This measure of property rights in not statistically significant.

Columns (4) and (5) employ two additional measures of property rights protection. These two measures are derived from other indexes. For instance, "enforcement" is an average of the efficiency of the judicial system, rule of law, risk of expropriation, and risk of contract repudiation. Similarly, the Knack and Keefer (1995) index of property rights protection is an additive index of corruption, rule of law, bureaucratic quality, contract repudiation, and risk of expropriation. The results show that both of these measures of property rights index have negative and statistically significant coefficient estimates.

Finally, Column (6) presents results that include both enforcement time and enforcement costs as inverse measures of property rights protection. Higher values of these measures reflect poor enforcement of property rights. We predict that both of these variables will have a positive coefficient in the loan spreads regression. The re-

\footnotetext{
${ }^{19}$ Jappelli et al. (2005) develop a model in which improvements in judicial efficiency reduce credit rationing and increase lending. However, the impact of improvements in judicial efficiency on interest rates is ambiguous, depending on banking competition and on the type of judicial reform.
} 
sults show that indeed longer enforcement time and higher enforcement costs both increase loan spreads.

\section{B. Additional control variables}

Table VII includes additional country-specific macroeconomic variables to the baseline regressions presented in Table IV. Four different macroeconomic variables are studied: (i) GDP growth volatility, (ii) liquid liabilities/GDP, (iii) stock market traded value/GDP, and (iv) credit to private sector/GDP.

GDP growth volatility is estimated as the standard deviation of the annual growth rate in GDP. It measures the volatility of economic activity. Higher volatility induces greater economic uncertainty raising the costs of financial contracting. The liquid liabilities/GDP ratio measures financial depth of an economy. Stock market total value traded/GDP measures the activity or liquidity of stock markets. Finally, the ratio of credit provided by financial intermediaries to the private sector to GDP ratio measures the financial development of an economy and the importance of the banking sector. All of these macroeconomic variables with the exception of GDP growth volatility are annual values and are obtained from the World Development Indicators database. We only report results from loan spreads in the table. Including additional macroeconomic variables to loan size and loan maturity regressions do not affect any of our previous conclusions.

Results reported in Table VII show that both the property rights protection and the creditor rights index continue to have negative and statistically significant coefficients even in the presence of these additional control variables. Table VII shows that GDP growth volatility has a positive and statistically significant coefficient, liquid liabilities/GDP ratio has a negative coefficient, and stock market traded value/GDP has a positive coefficient. The coefficient estimate on the credit to private sector is statistically insignificant. 


\section{Lending around Asian financial crisis}

How did bank loan contracts respond to the East Asian financial crisis of 1997-98? The crisis can be considered relatively exogenous (at least from the perspective of any single firm). While the crisis did not materially change the property rights and creditor rights index for any of the affected countries during that short period, it did significantly reduce expected rates of return on investments. Johnson et al. (2000) and Lemmon and Lins (2003) argue that during the crisis, as the expected rate of return on investment fell, the incentives for controlling shareholders to expropriate other stakeholders increased. Thus, when growth prospects decline, legal rights of lenders and contract enforceability becomes relatively more important. To paraphrase Johnson et al. (2000), institutions matter a great deal more during times of crisis.

If creditor rights and enforcement of contracts affect bank lending, one would expect that during periods of crisis, firms operating in countries with weak creditor rights and poor enforcement will face relatively deeper cuts in loan volumes, more severe reduction in loan maturities, and a larger increase in loan spreads. We test these predictions in Table VIII.

The East Asian financial crisis began in July 1997 with the initial devaluation of Thailand. Although the end-point of the crisis is debatable, many observers believe that it ended in August 1998 (see Johnson et al. (2000), Lemmon and Lins (2003) and Mitton (2002)). Most stock markets had begun to recover by this time. Thus, we define the period between July 1, 1997 and August 31, 1998 to be the crisis period. None of our results are affected if we use January 1999 or April 1999 as the alternative ending points. The eight East Asian countries affected by the crisis include (1) Indonesia, (2) Malaysia, (3) Philippines, (4) South Korea, (5) Thailand, (6) Hong Kong, (7) Singapore, and (8) Taiwan. Mitton (2002) considers five countries from this list excluding Hong Kong, Singapore, and Taiwan. None of our results depend on including or excluding these three countries. Unreported results show that the effects are actually stronger if we exclude Hong Kong, Singapore and Taiwan from this list of affected countries.

The empirical strategy is to include additional interaction terms (a) between the crisis period and East Asian region dummy and (b) between the crisis period and property rights and creditor rights indices to the baseline regressions reported in Columns 
(7) to (9) of Table IV. If banks cut back on lending to firms in East Asian countries during the 1997-98 crisis, the interaction terms between East Asia and crisis period should be negative in the loan size regressions (reporetd in Columns (1) and (2) of Table VIII). If property rights matter, banks would lend relatively more to firms in countries with better enforcement during crisis periods relative to firms in other countries with weaker protection of rights. Thus, in the loan size regression, the interaction term between property rights and crisis period and that between creditor rights and the crisis period should be positive. The results in Table VIII provide weak evidence that loan volumes responded to variation in creditor rights and property rights during the crisis periods.

Column (3) and (4) present results from random effects estimation of loan maturity. We find that loan maturities significantly declined for East Asian borrowers during the 1997-98 crisis period. The coefficients on the interaction between property rights and crisis and that between creditor rights and crisis are both positive, as predicted, although neither is significant.

Columns (5) and (6) present results from loan spreads regressions with additional interaction terms. As the crisis unfolded, credit risks increased and banks responded by increasing loan spreads. The interaction term between East Asian region and crisis indicator variable is positive and statistically significant at the one percent level in both specifications. The coefficient on interaction between property rights and crisis is significantly negative suggesting that during crisis periods, loans to firms in countries with strong enforcement have relatively lower spreads compared to firms in countries with weak enforcement. The coefficient on the interaction between creditor rights and crisis period is also negative and significant at the 5 percent level, suggesting that spreads are lower in countries with stronger creditor rights compared to those that have weaker creditor rights.

As Figure 4(a) shows, median loan spreads to firms in East Asian countries increase sharply around the beginning of crisis period and declined at the end of the crisis period. Figure 4(b) shows that the median spreads to Latin American countries increased around the end of 1998 and declined sharply by the beginning of 1999. Median spreads to firms in Europe (shown in Figure 4(c)) exhibit no such trend. Figures 5(a), 5(b) and 
5(c) show aggregate loan volumes. These figures show that loan volumes fell dramatically during the early part of the crisis and then recovered as the crisis receded.

In addition, we test if incentive problems are more severe in firms with fewer tangible assets. In unreported regressions, we find that an interaction term between tangibility and crisis dummy is significantly negative in the spread regressions. This suggests that greater tangibility of assets lowered loan spreads for borrowers in East Asian countries during the crisis period.

In summary, these results indicate the response of loan contracts to variation in creditor rights and contract enforceability is significantly higher during financial crisis when monitoring and recontracting costs are of particular importance to lenders.

\section{Conclusion}

Some countries provide stronger creditor rights and better protection of property rights than do other countries. Do differences in laws and contract enforcement affect loan quantities, loan maturity, and costs of loan finance? We examine this question with a large sample of loans to borrowers in 48 countries during the 1994-2003 period.

The results support the view that property rights protection results in more efficient contracting. Banks lend more, offer longer maturity loans, and charge lower spreads on loans to borrowers in countries where property rights are well protected. We find that creditor rights matter only for loan spreads. Differences in creditor rights are not systematically related to loan sizes and loan maturities. Even for spreads, the effects of creditor rights are weaker than the effect that differences in enforcement have on spreads.

In a further experiment, we examine loans to firms in East Asian countries during the financial crisis of 1997-98. The crisis increased monitoring and recontracting costs for lenders. Banks responded by shortening loan maturities and by increasing spreads. The increase in spreads during the crisis period is particularly pronounced for borrowers in countries that have weak creditor rights and poor contract enforceability. 


\section{References}

Acemoglu, Daron, Simon Johnson, and James A. Robinson, 2001, The colonial origins of comparative development: An empirical investigation, American Economic Review 91, 1369-1401.

Baltagi, Badi H., 2001, Econometric analysis of panel data (Wiley and Sons, UK).

Beck, Nathaniel, 2001, Time-series cross-section data: What have we learned in the past few years?, Annual Review of Political Science 4, 271-93.

Besley, Timothy, 1995, Property rights and investment incentives: Theory and evidence from ghana, Journal of Political Economy 103, 903-937.

Bhattacharya, Utpal, and Hazem Daouk, 2002, The world price of insider trading, Journal of Finance 57, 75-108.

Bhattacharya, Utpal, and Hazem Daouk, 2005, When no law is better than a good law, Working paper, Indiana University and Cornell University.

Breusch, T., and A. Pagan, 1980, The LM test and its application to model specification in econometrics, Review of Economic Studies 47, 239-254.

Cantor, Richard, and Frank Packer, 1997, Differences of opinion and selection bias in the credit rating industry, Journal of Banking and Finance 21, 1395-1417.

Claessens, Stijn, Simeon Djankov, Joseph Fan, and Larry Lang, 2002, Disentangling the incentive and entrenchment effects of large shareholdings, Journal of Finance 57, 2741-2771.

Demirgüç-Kunt, A., and V. Maksimovic, 1998, Law, finance, and firm growth., Journal of Finance 53, 2107-2137.

Demirgüç-Kunt, A., and V. Maksimovic, 1999, Institutions, financial markets, and firm debt maturity, Journal of Financial Economics 54, 295-336.

Desai, Mihir A., C. Fritz Foley, and James R. Hines, 2004, A multinational perspective on capital structure choice and internal capital markets, Journal of Finance 59, 24512488.

Diamond, Douglas, 2004, Presidential address - committing to commit: short-term debt when enforcement is costly, Journal of Finance 59, 1447-1480.

Diamond, Douglas W., 1991, Debt maturity and liquidity risk, Quarterly Journal of Economics 106, 709-737.

Diamond, Douglas W., 1993, Seniority and maturity of debt contracts, Journal of Financial Economics 33, 341-368. 
Djankov, Simeon, Caralee McLeish, and Andrei Shleifer, 2007, Private credit in 129 countries., Journal of Financial Economics 84, 299-329.

Esty, Benjamin C., 2001, Structuring loan syndicates: A case study of the hong kong disneyland project loan, Journal of Applied Corporate Finance 13, 3-23.

Esty, Benjamin C., 2004, Why study large projects? an introduction to research on project finance, European Financial Management 213-224.

Esty, Benjamin C., 2006, When do foreign banks finance domestic investment? New evidence on the importance of legal and financial systems., working paper, Harvard Business School.

Esty, Benjamin C., and William L. Megginson, 2003, Creditor rights, enforcement, and debt ownership structure: Evidence from the global syndicate loan market, Journal of Financial and Quantitative Analysis 37-59.

Hail, Luzi, and Christian Luez, 2006, International differences in cost of capital: Do legal institutions and securities regulation matter?, Journal of Accounting Research 44, 485-531.

Hsiao, Cheng, 2003, Analysis of panel data (Cambridge University Press, Cambridge).

Jappelli, Tullio, Marco Pagano, and Magda Bianco, 2005, Courts and banks: Effects of judicial enforcement on credit markets, Journal of Money, Credit and Banking forthcoming.

Johnson, Simon, Peter Boone, Alasdair Breach, and Eric Friedman, 2000, Corporate governance in the asian financial crisis, Journal of Financial Economics 58, 141-186.

Knack, Stephen, and Philip Keefer, 1995, Institutions and economic performance: Cross country tests using alternative institutional measures, Economics and Politics 7, 207227.

La Porta, Rafael, Florencio Lopez-de Silanes, Andrei Shleifer, and Robert W. Vishny, 1997, Legal determinants of external finance, Journal of Finance 52, 1131-1155.

La Porta, Rafael, Florencio Lopez-de Silanes, Andrei Shleifer, and Robert W. Vishny, 1998, Law and finance, Journal of Political Economy 106, 1113-1150.

La Porta, Rafael, Florencio Lopez-de Silanes, Andrei Shleifer, and Robert W. Vishny, 2002a, Investor protection and corporate governance, Journal of Financial Economics $58,3-27$.

La Porta, Rafael, Florencio Lopez-de Silanes, Andrei Shleifer, and Robert W. Vishny, 2002b, Investor protection and corporate valuation, Journal of Finance 57, 1147-1170. 
Laeven, Luc, and Giovanni Majnoni, 2005, Does judicial efficiency lower the cost of credit?, Journal of Banking and Finance 29, 1791-1812.

Lemmon, Michael L., and Karl V. Lins, 2003, Ownership structure, corporate governance, and firm value: Evidence from the east asian financial crisis, Journal of Finance $58,1445-1468$.

Levine, Ross, 1999, Law, finance and economic growth, Journal of Financial Intermediation 8, 8-35.

Levine, Ross, Thorsten Beck, and Norman Loyaza, 2000, Financial intermediation and growth: Causality and causes, Journal of Monetary Economics 46, 31-77.

Mauro, Paolo, 1995, Corruption and growth, Quarterly Journal of Economics 110, 681712.

Miller, Darius P., and John J. Puthenpurackal, 2002, The costs, wealth effects, and determinants of international capital raising: Evidence from public yankee bonds, Journal of Financial Intermediation 11, 455-485.

Mitton, Todd, 2002, A cross-firm analysis of the impact of corporate governance on the east asian financial crisis, Journal of Financial Economics 64, 215-241.

Morck, Randall, Bernard Yeung, and Wayne Yu, 2000, The information content of stock markets: Why do emerging markets have synchronous stock price movements?, Journal of Financial Economics 58, 215-260.

Myers, Stewart C., 1977, Determinants of corporate borrowing, Journal of Financial Economics 5, 147-175.

Petersen, Mitchell A., 2007, Estimating standard errors in finance panel data sets: Comparing approaches, Review of Financial Studies, Forthcoming .

Pinheiro, Armando Castelar, and Célia Cabral, 1999, Credit markets in brazil: The role of judicial enforcement and other institutions, Working Paper R-368, BID .

Plümper, Thomas, and Vera E. Troeger, 2007, Efficient estimation of time-invariant and rarely changing variables in finite sample panel analysis with unit fixed effects, $\mathrm{Po}$ litical Analysis 15, 124-139.

Qian, Jun, and Philip E. Strahan, 2007, How law and institutions shape financial contracts: The case of bank loans, Journal of Finance, Forthcoming .

Rajan, Raghuram, and Luigi Zingales, 1998, Financial dependence and growth, American Economic Review 88, 559-586.

Stiglitz, Joseph E., and Andrew Weiss, 1981, Credit rationing in markets with imperfect information, American Economic Review 71, 393-410. 
Strahan, Philip E., 1999, Borrower risk and the price and nonprice terms of bank loans Working paper, Federal Reserve Bank of New York.

Sufi, Amir, 2007, Information asymmetry and financing arrangements: Evidence from syndicated loans, Journal of Finance 62, 629-668.

Woolridge, J.M., 2002, Econometric analysis of cross section and panel data (The MIT Press, Cambridge Massachusetts). 


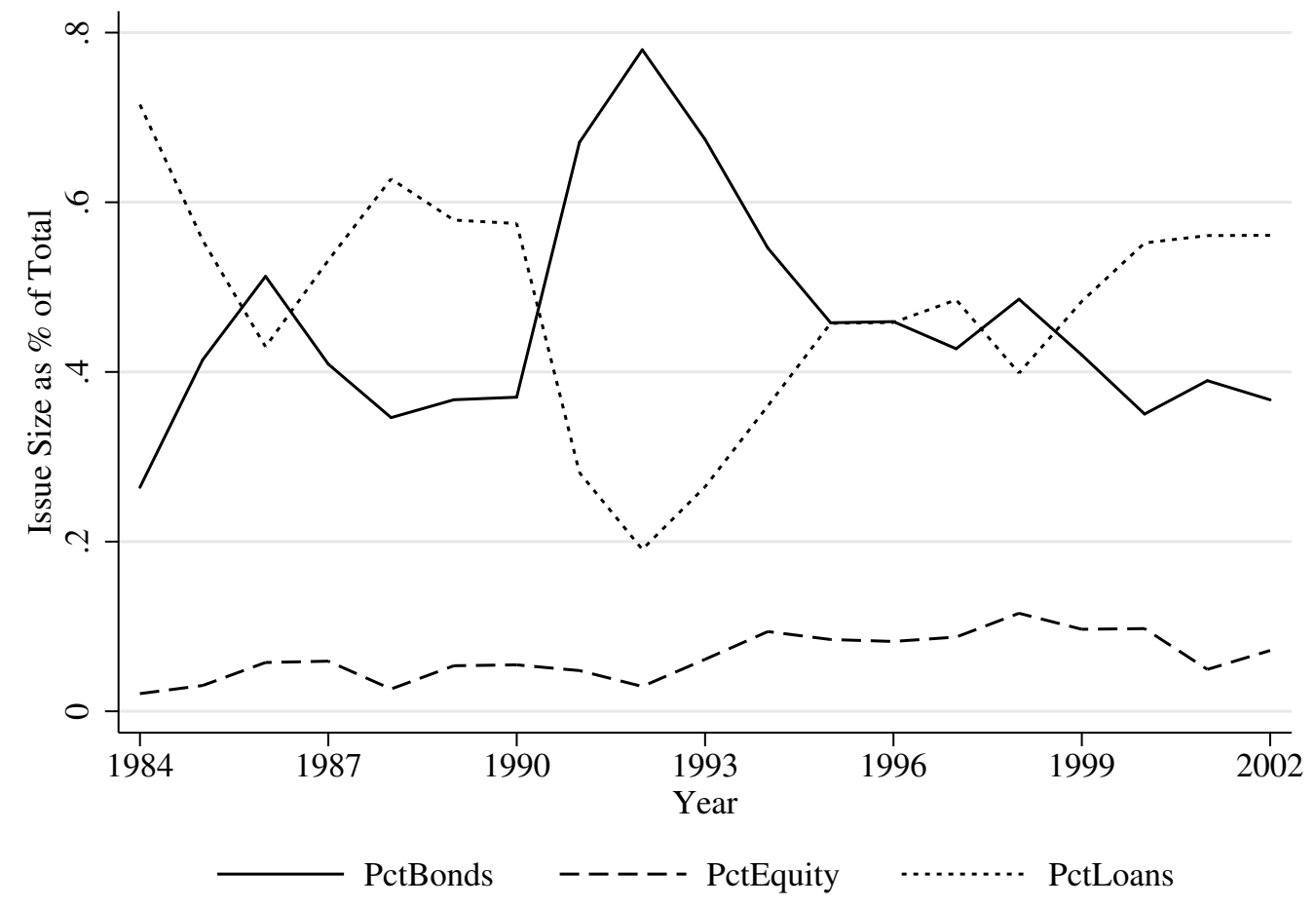

Figure 1 Relative importance of different forms of financing for 49 countries. Bond and equity issuance data are from the SDC database provided by Thomson Financial and the loan data are from the Loan Pricing Corporation. 


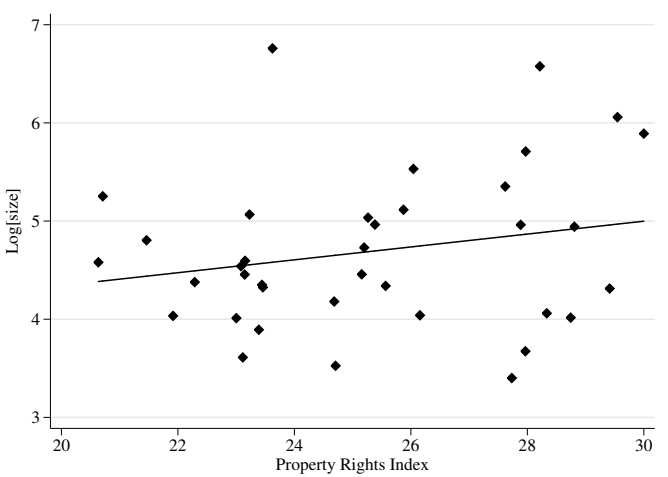

(a) Loan size and property rights

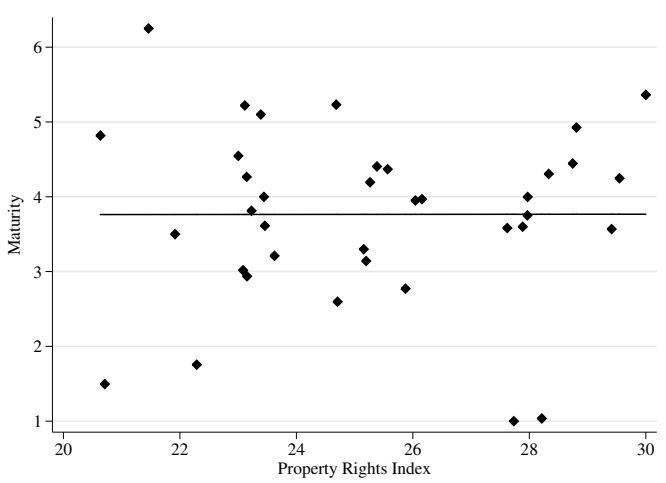

(c) Loan maturity and property rights

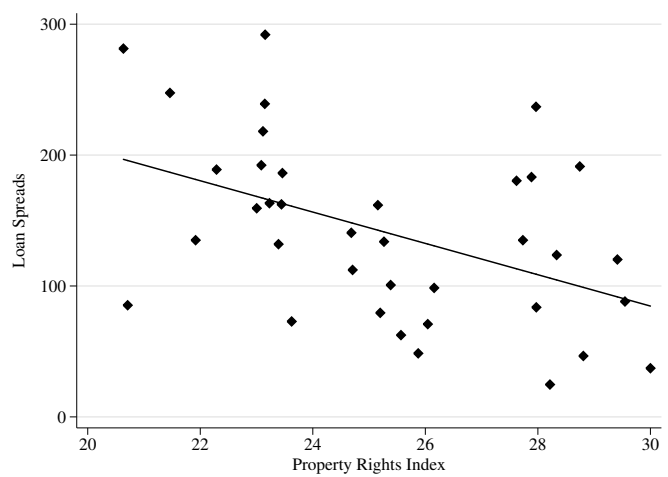

(e) Loan spreads and property rights

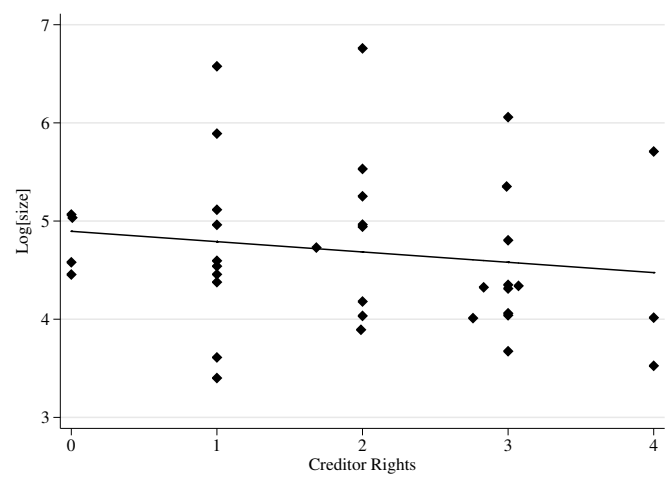

(b) Loan size and creditor rights

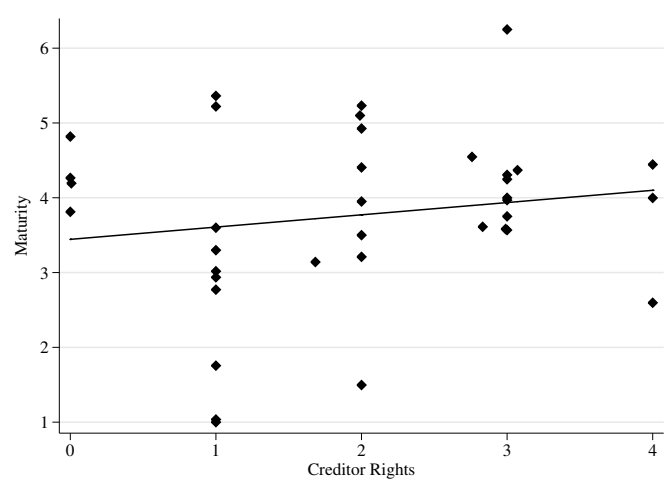

(d) Loan maturity and creditor rights

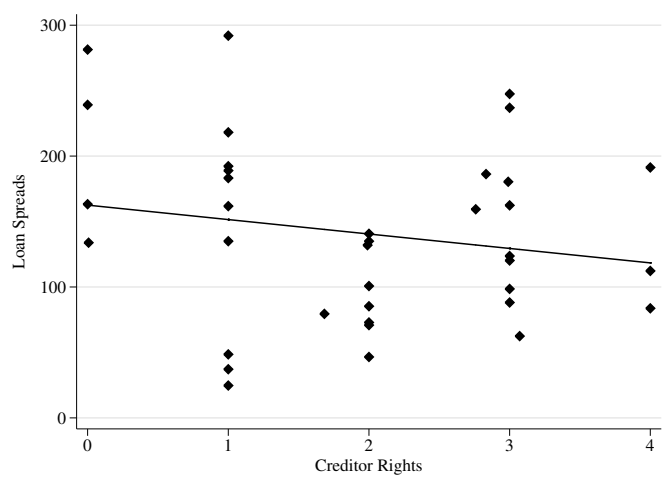

(f) Loan spreads and creditor rights

Figure 2 Prediction and scatter plots of median loan size, median loan maturity, and median loan spread against property rights and creditor rights. 

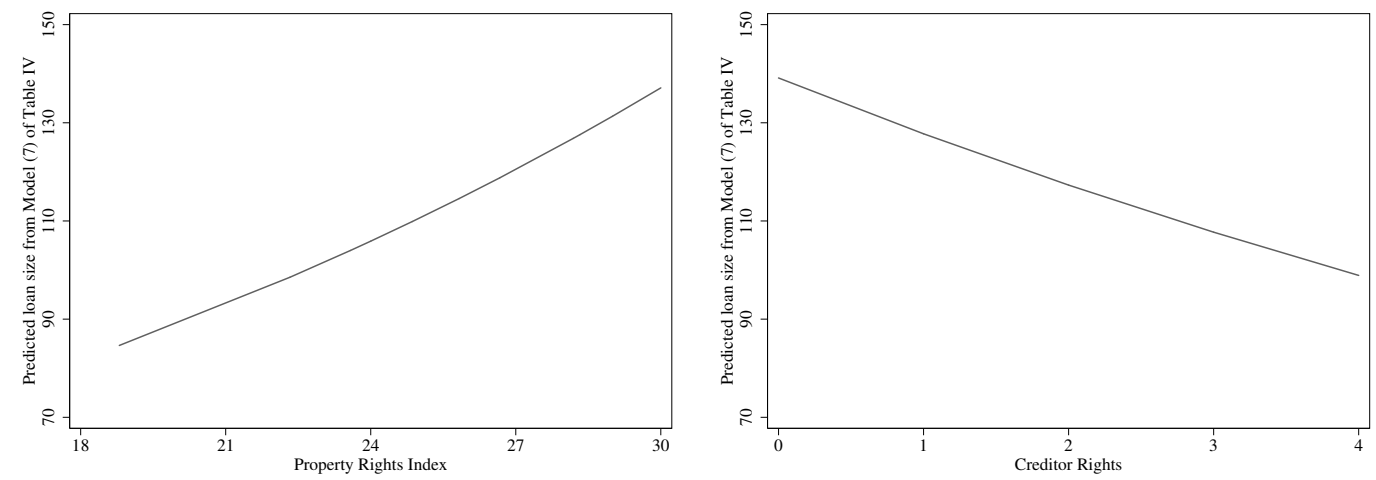

(a) Predicted loan size versus property rights (b) Predicted loan size versus creditor rights
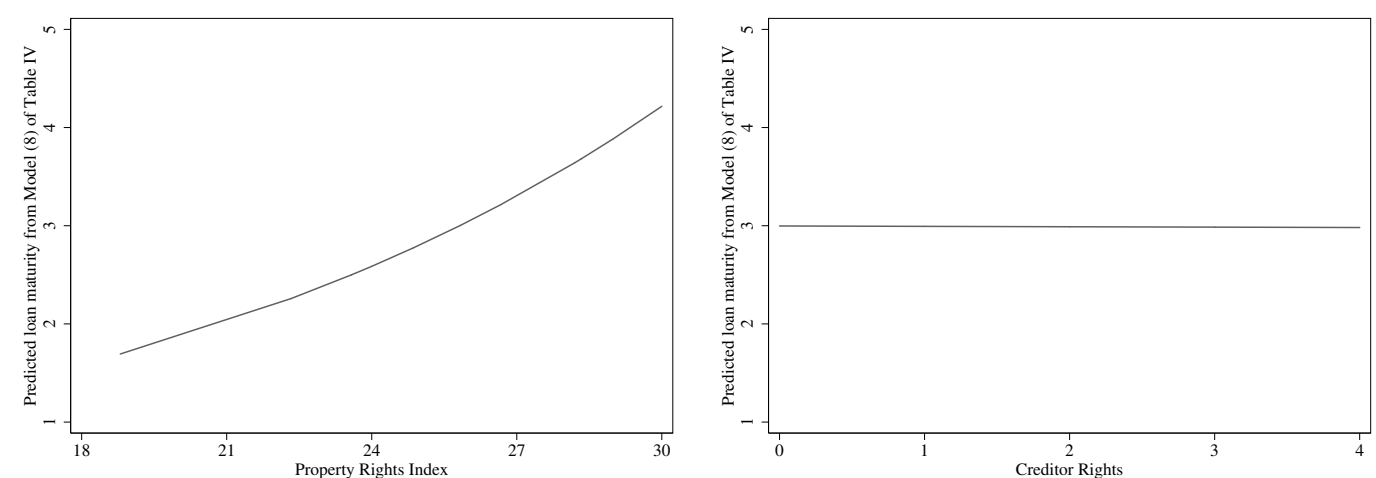

(c) Predicted maturity versus property rights (d) Predicted maturity versus creditor rights
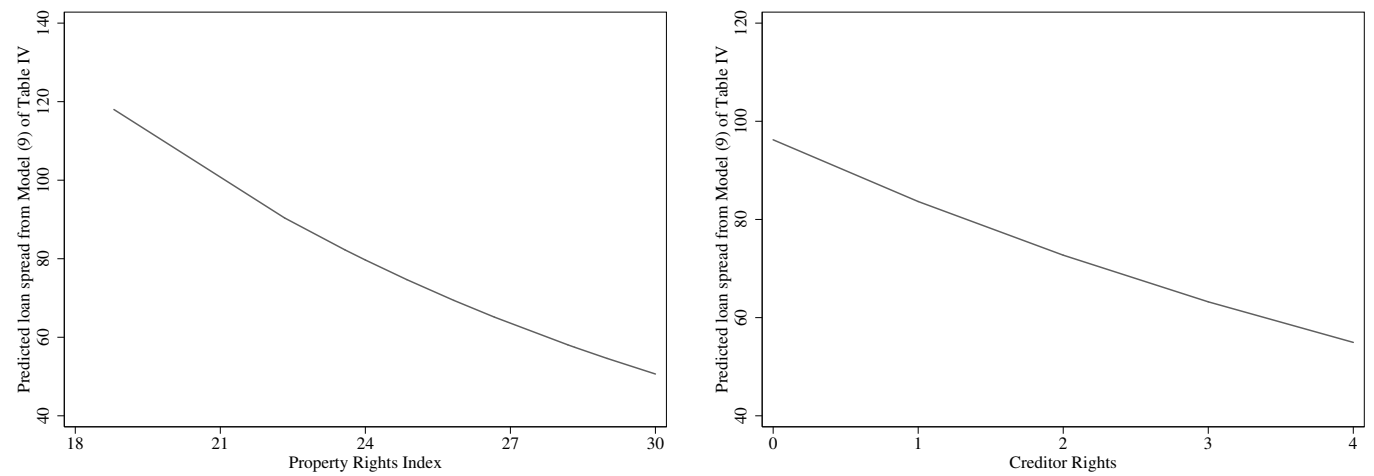

(e) Predicted spreads versus property rights

(f) Predicted spreads versus creditor rights

Figure 3 Predicted loan sizes, loan maturities and loan spreads from models (7) to (9) of Table IV at various values of property rights and creditor rights (all other variables are held at their respective means). 


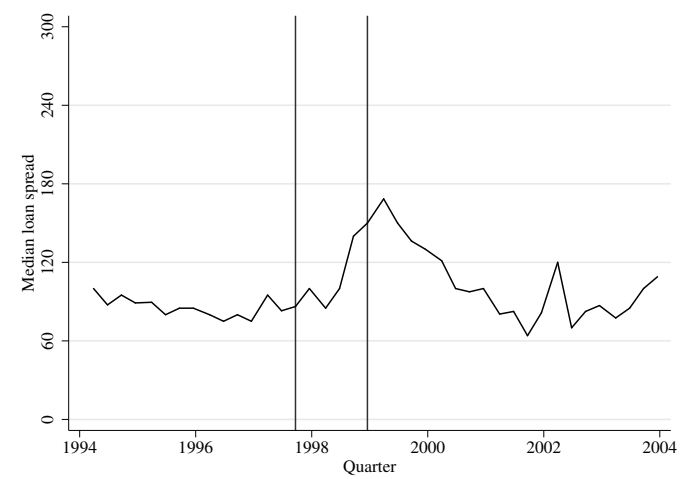

(a) East Asia

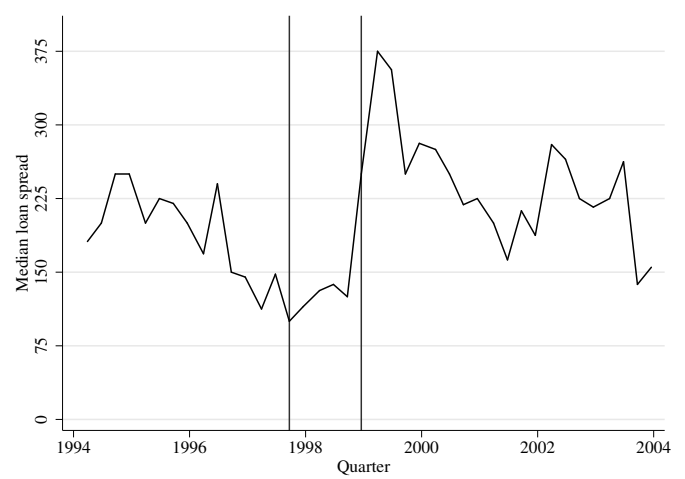

(b) Latin America

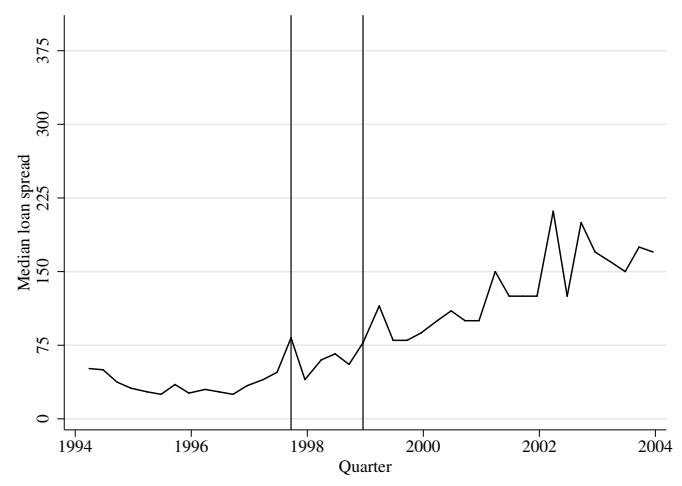

(c) Europe

Figure 4 Plot of median loan spreads estimated at quarterly frequency for East Asia, Latin America and Europe. The crisis period is indicated by two vertical lines and spans from 1997-III to 1998-III. The sample includes all loans from Loan Pricing Corporation database during 1994-2003 period. East Asia includes Hong Kong, Indonesia, Korea, Malaysia, Philippines, Singapore, Thailand, and Taiwan. Latin America includes Argentina, Brazil, Chile, Colombia, Mexico, Peru, Venezuela, and Ecuador. Europe includes Belgium, Denmark, France, Germany, Italy, Netherlands, Ireland, Finland, Spain, Sweden, Switzerland, UK, Norway, Austria, Greece, and Portugal. 


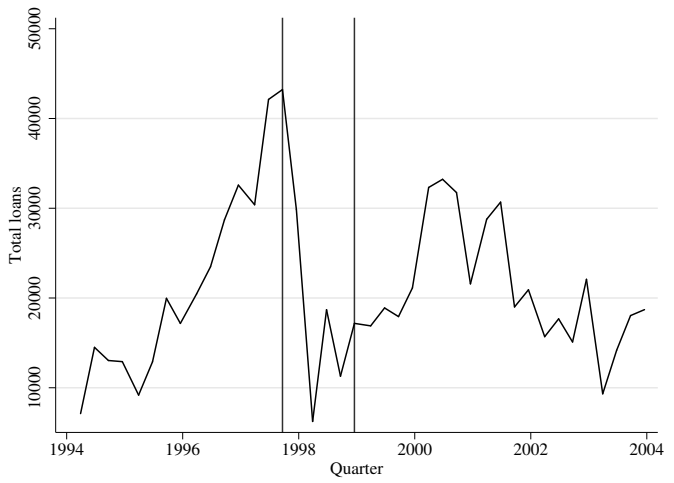

(a) East Asia

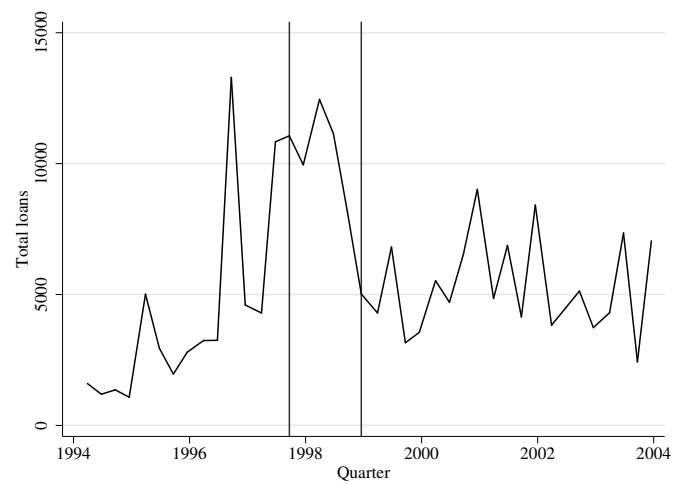

(b) Latin America

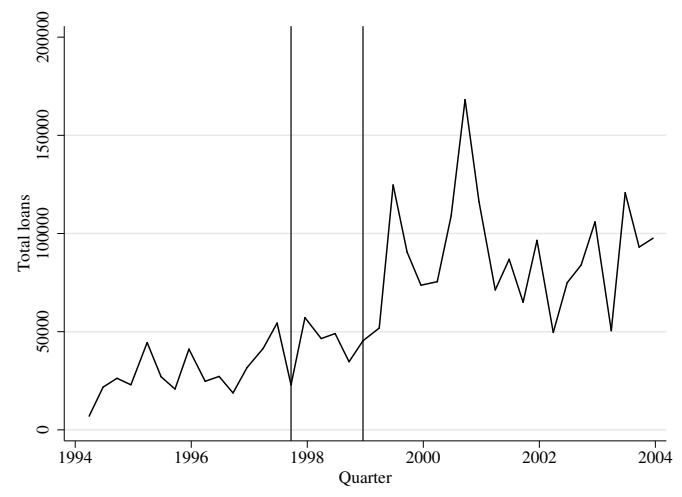

(c) Europe

Figure 5 Plot of aggregate loan amounts estimated at quarterly frequency for East Asia, Latin America, and Europe. The crisis period is indicated by two vertical lines and spans from 1997-III to 1998-III. The sample includes all loans from Loan Pricing Corporation database during 1994-2003 period. East Asia includes Hong Kong, Indonesia, Korea, Malaysia, Philippines, Singapore, Thailand, and Taiwan. Latin America includes Argentina, Brazil, Chile, Colombia, Mexico, Peru, Venezuela, and Ecuador. Europe includes Belgium, Denmark, France, Germany, Italy, Netherlands, Ireland, Finland, Spain, Sweden, Switzerland, UK, Norway, Austria, Greece, and Portugal. 
Table I

Summary statistics for loan transactions

This table presents summary statistics for a sample of 17,791 loan tranches to firms matched to the Worldscope database in 38 countries. The sample period is 1994-2003. Summary statistics are presented for the median loan and borrower characteristics at the country level (except for the indicator variables). Leverage is the ratio of total debt to book assets. Profitability is the ratio of operating income to total assets. Tangibility is the ratio of net property, plant and equipment to total assets. The market-to-book assets ratio is the ratio of the market value of assets to the book value of assets.

\begin{tabular}{|c|c|c|c|c|c|}
\hline & \multirow[b]{2}{*}{ Mean } & \multirow[b]{2}{*}{$S D$} & \multicolumn{2}{|c|}{ Distribution } & \multirow[b]{2}{*}{$90^{t h}$} \\
\hline & & & $10^{t h}$ & $50^{t h}$ & \\
\hline \multicolumn{6}{|l|}{ Enforcement and creditor rights } \\
\hline Median property rights index & 25.39 & 2.63 & 21.92 & 25.07 & 28.72 \\
\hline Median creditor rights index & 1.92 & 1.17 & 0.00 & 2.00 & 3.00 \\
\hline \multicolumn{6}{|l|}{ Loan characteristics } \\
\hline Median loan spread (basis points) & 105.30 & 69.52 & 35.00 & 82.50 & 247.50 \\
\hline Median loan maturity (years) & 3.62 & 1.40 & 1.00 & 3.50 & 5.00 \\
\hline Median loan size ( $\$$ millions) & 161 & 172 & 30 & 100 & 343 \\
\hline Secured loans $(\%)$ & 10.05 & 12.59 & 0.00 & 4.14 & 29.70 \\
\hline Senior loans (\%) & 73.95 & 34.26 & 15.75 & 93.75 & 100.00 \\
\hline Agency loans (\%) & 4.31 & 8.51 & 0.00 & 0.49 & 12.12 \\
\hline \multicolumn{6}{|l|}{ Syndicate structure } \\
\hline Median syndicate size (\# lenders) & 9.47 & 4.24 & 4.00 & 8.00 & 15.50 \\
\hline Share of biggest lender (\%) & 15.52 & 8.09 & 6.50 & 14.29 & 27.63 \\
\hline Syndicate concentration-Herfindahl (\%) & 13.34 & 7.59 & 4.76 & 11.52 & 25.00 \\
\hline Median \# of foreign banks & 6.24 & 4.28 & 1.00 & 6.00 & 13.00 \\
\hline Median foreign banks as $\%$ of total & 64.64 & 28.17 & 25.00 & 77.78 & 94.12 \\
\hline$\%$ loan kept by foreign banks & 60.97 & 28.59 & 22.22 & 69.57 & 91.67 \\
\hline \multicolumn{6}{|l|}{ Loan purpose indicators } \\
\hline Working capital/corporate purposes & 0.44 & 0.24 & & & \\
\hline Capital expenditure/asset financing & 0.05 & 0.08 & & & \\
\hline Refinancing & 0.20 & 0.12 & & & \\
\hline Acquisitions/recapitalization & 0.12 & 0.16 & & & \\
\hline Backup line & 0.02 & 0.03 & & & \\
\hline Other & 0.17 & 0.21 & & & \\
\hline \multicolumn{6}{|l|}{ Firm characteristics } \\
\hline Median total assets ( $\$$ millions) & 12,822 & 29,391 & 824 & 3,308 & 37,190 \\
\hline Median profitability & 0.06 & 0.03 & 0.01 & 0.06 & 0.11 \\
\hline Median leverage & 0.33 & 0.09 & 0.21 & 0.32 & 0.46 \\
\hline Median tangibility & 0.37 & 0.21 & 0.02 & 0.39 & 0.66 \\
\hline Median market-to-book ratio & 1.17 & 0.22 & 0.97 & 1.14 & 1.39 \\
\hline
\end{tabular}




\section{Table II \\ Loan and borrower characteristics by property rights}

This table presents median of median loan and borrower characteristics (except for indicator variables where it presents medians of averages) for countries classified based on property rights index, an additive index consisting of annual series reflecting corruption, risk of expropriation, and risk of contract repudiation in various countries. Weak property rights countries are in the bottom one-third, medium property rights countries are in the middle one-third, and strong property rights countries are in top one-third of property rights index. The sample consists of 17,791 loans to borrowers with Worldscope data. The sample is from 1994 to 2003 and covers 38 countries. The medians for US loans are presented separately. Leverage is the ratio of total debt to book assets. Profitability is the ratio of operating income to total assets. Tangibility is the ratio of net property, plant and equipment to total assets. The market-to-book assets ratio is the ratio of the market value of assets to the book value of assets.

\begin{tabular}{lrrrrr}
\hline & \multicolumn{3}{c}{ Property Rights } & & \\
\cline { 2 - 3 } & Weak & Medium & Strong & US & Total \\
\hline Enforcement and creditor rights & & & & & \\
Median property rights index & 23.03 & 25.00 & 28.33 & 26.67 & 25.07 \\
Median creditor rights index & 1.00 & 2.00 & 3.00 & 1.00 & 2.00 \\
Loan characteristics & & & & & \\
Median loan spread (basis points) & 150.00 & 75.00 & 49.25 & 175.00 & 82.50 \\
Median loan maturity (years) & 3.50 & 3.50 & 4.54 & 3.00 & 3.50 \\
Median loan size (\$ millions) & 95 & 102 & 109 & 103 & 100 \\
Secured loans indicator (\%) & 9.09 & 6.25 & 2.53 & 49.65 & 4.14 \\
Senior loans indicator (\%) & 100.00 & 85.71 & 95.61 & 97.18 & 93.75 \\
Agency loans indicator (\%) & 6.16 & 0.35 & 0.00 & 0.05 & 0.49 \\
Syndicate structure & & & & & \\
Median syndicate size (\# lenders) & 7.00 & 10.00 & 11.00 & 7.00 & 8.00 \\
Share of biggest lender (\%) & 17.94 & 14.29 & 9.09 & 16.67 & 14.29 \\
Syndicate concentration-Herfindahl (\%) & 14.29 & 10.50 & 8.78 & 14.29 & 11.52 \\
Median \# of foreign banks & 5.50 & 6.00 & 8.50 & 2.00 & 6.00 \\
Median foreign banks as \% of total & 85.19 & 57.89 & 76.39 & 25.00 & 77.78 \\
\% loan kept by foreign banks & 85.71 & 50.82 & 65.38 & 22.22 & 69.57 \\
Loan purpose indicators & & & & & \\
Working capital/corporate purposes & 0.49 & 0.39 & 0.46 & 0.39 & 0.44 \\
Capital expenditure/asset financing & 0.08 & 0.07 & 0.02 & 0.02 & 0.05 \\
Refinancing & 0.20 & 0.20 & 0.19 & 0.24 & 0.20 \\
Acquisitions /recapitalization & 0.03 & 0.13 & 0.17 & 0.21 & 0.12 \\
Backup line & 0.01 & 0.01 & 0.03 & 0.11 & 0.02 \\
Other & 0.19 & 0.21 & 0.13 & 0.02 & 0.17 \\
Firm characteristics & & & & & \\
Median total assets (\$ millions) & 2,408 & 3,309 & 5,391 & 663 & 3,309 \\
Median profitability & 0.09 & 0.05 & 0.05 & 0.08 & 0.06 \\
Median leverage & 0.30 & 0.36 & 0.33 & 0.31 & 0.32 \\
Median tangibility & 0.54 & 0.39 & 0.32 & 0.26 & 0.39 \\
Median market-to-book ratio & 1.23 & 1.15 & 1.09 & 1.37 & 1.14 \\
\hline & & & & & \\
\hline
\end{tabular}


Table III

\section{Loan and borrower characteristics by creditor rights}

This table presents median of median loan and borrower characteristics (except for indicator variables where it presents medians of averages) for countries classified based on based on the strength of creditor rights. The creditor rights index varies from 0 (poor creditor rights) to 4 (strong creditor rights) (Djankov et al., 2007). Weak creditor rights countries are countries with creditor rights index of 1 or less, medium creditor rights countries are countries with creditor rights index between 1 and 3 , and strong creditor rights countries are countries with creditor rights index of 3 or higher. The sample consists of 17,791 loans to borrowers with Worldscope data. The sample is from 1994 to 2003 and covers 38 countries. The medians for US loans are presented separately. Leverage is the ratio of total debt to book assets. Profitability is the ratio of operating income to total assets. Tangibility is the ratio of net property, plant and equipment to total assets. The market-to-book assets ratio is the ratio of the market value of assets to the book value of assets.

\begin{tabular}{|c|c|c|c|c|c|}
\hline & \multicolumn{3}{|c|}{ Creditor Rights } & \multirow[b]{2}{*}{ US } & \multirow[b]{2}{*}{ Total } \\
\hline & Weak & Medium & Strong & & \\
\hline \multicolumn{6}{|l|}{ Enforcement and creditor rights } \\
\hline $\begin{array}{l}\text { Median property rights index } \\
\text { Median creditor rights index }\end{array}$ & $\begin{array}{r}24.38 \\
1.00\end{array}$ & $\begin{array}{r}24.50 \\
2.00\end{array}$ & $\begin{array}{r}28.19 \\
3.00\end{array}$ & $\begin{array}{r}26.67 \\
1.00\end{array}$ & $\begin{array}{r}25.07 \\
2.00\end{array}$ \\
\hline \multicolumn{6}{|l|}{ Loan characteristics } \\
\hline $\begin{array}{l}\text { Median loan spread (basis points) } \\
\text { Median loan maturity (years) } \\
\text { Median loan size (\$ millions) } \\
\text { Secured loan indicator }(\%) \\
\text { Senior loan indicator }(\%) \\
\text { Agency loan indicator }(\%)\end{array}$ & $\begin{array}{r}143.75 \\
3.00 \\
136 \\
7.10 \\
95.95 \\
5.20\end{array}$ & $\begin{array}{r}75.00 \\
3.75 \\
105 \\
2.67 \\
80.60 \\
0.46\end{array}$ & $\begin{array}{r}60.00 \\
4.92 \\
61 \\
3.44 \\
88.71 \\
0.00\end{array}$ & $\begin{array}{r}175.00 \\
3.00 \\
103 \\
49.65 \\
97.18 \\
0.05\end{array}$ & $\begin{array}{r}82.50 \\
3.50 \\
100 \\
4.14 \\
93.75 \\
0.49\end{array}$ \\
\hline $\begin{array}{l}\text { Syndicate structure } \\
\text { Median syndicate size (\# lenders) } \\
\text { Share of biggest lender (\%) } \\
\text { Syndicate concentration-Herfindahl (\%) } \\
\text { Median \# of foreign banks } \\
\text { Median foreign banks as \% of total } \\
\% \text { loan kept by foreign banks }\end{array}$ & $\begin{array}{r}8.00 \\
14.29 \\
12.50 \\
6.00 \\
84.62 \\
82.23\end{array}$ & $\begin{array}{r}10.50 \\
12.33 \\
9.66 \\
5.50 \\
55.65 \\
48.12\end{array}$ & $\begin{array}{r}8.00 \\
15.19 \\
11.20 \\
4.00 \\
75.00 \\
61.20\end{array}$ & $\begin{array}{r}7.00 \\
16.67 \\
14.29 \\
2.00 \\
25.00 \\
22.22\end{array}$ & $\begin{array}{r}8.00 \\
14.29 \\
11.52 \\
6.00 \\
77.78 \\
69.57\end{array}$ \\
\hline $\begin{array}{l}\text { Loan purpose indicators } \\
\text { Working capital/corporate purposes } \\
\text { Capital expenditure/asset financing } \\
\text { Refinancing } \\
\text { Acquisitions/recapitalization } \\
\text { Backup line } \\
\text { Other }\end{array}$ & $\begin{array}{l}0.48 \\
0.05 \\
0.18 \\
0.14 \\
0.02 \\
0.12\end{array}$ & $\begin{array}{l}0.41 \\
0.07 \\
0.20 \\
0.10 \\
0.01 \\
0.20\end{array}$ & $\begin{array}{l}0.44 \\
0.03 \\
0.20 \\
0.10 \\
0.02 \\
0.21\end{array}$ & $\begin{array}{l}0.39 \\
0.02 \\
0.24 \\
0.21 \\
0.11 \\
0.02\end{array}$ & $\begin{array}{l}0.44 \\
0.05 \\
0.20 \\
0.12 \\
0.02 \\
0.17\end{array}$ \\
\hline \multicolumn{6}{|l|}{ Firm characteristics } \\
\hline $\begin{array}{l}\text { Median total assets (\$ mill.) } \\
\text { Median profitability } \\
\text { Median leverage } \\
\text { Median tangibility } \\
\text { Median market-to-book ratio }\end{array}$ & $\begin{array}{r}2,554 \\
0.07 \\
0.32 \\
0.49 \\
1.24\end{array}$ & $\begin{array}{r}2,891 \\
0.05 \\
0.36 \\
0.41 \\
1.10\end{array}$ & $\begin{array}{r}5,463 \\
0.05 \\
0.28 \\
0.35 \\
1.08\end{array}$ & $\begin{array}{l}663 \\
0.08 \\
0.31 \\
0.26 \\
1.37\end{array}$ & $\begin{array}{r}3,309 \\
0.06 \\
0.32 \\
0.39 \\
1.14\end{array}$ \\
\hline
\end{tabular}




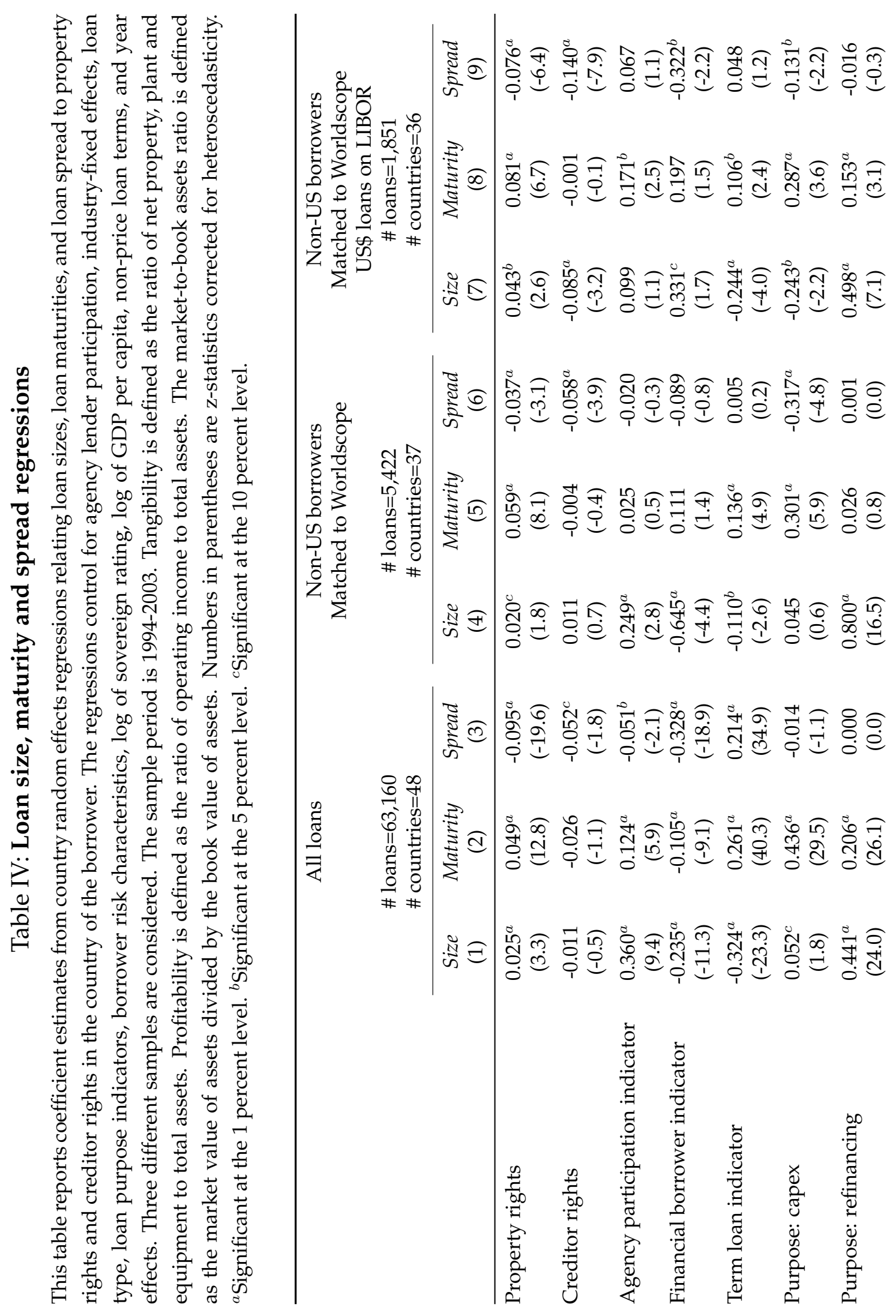




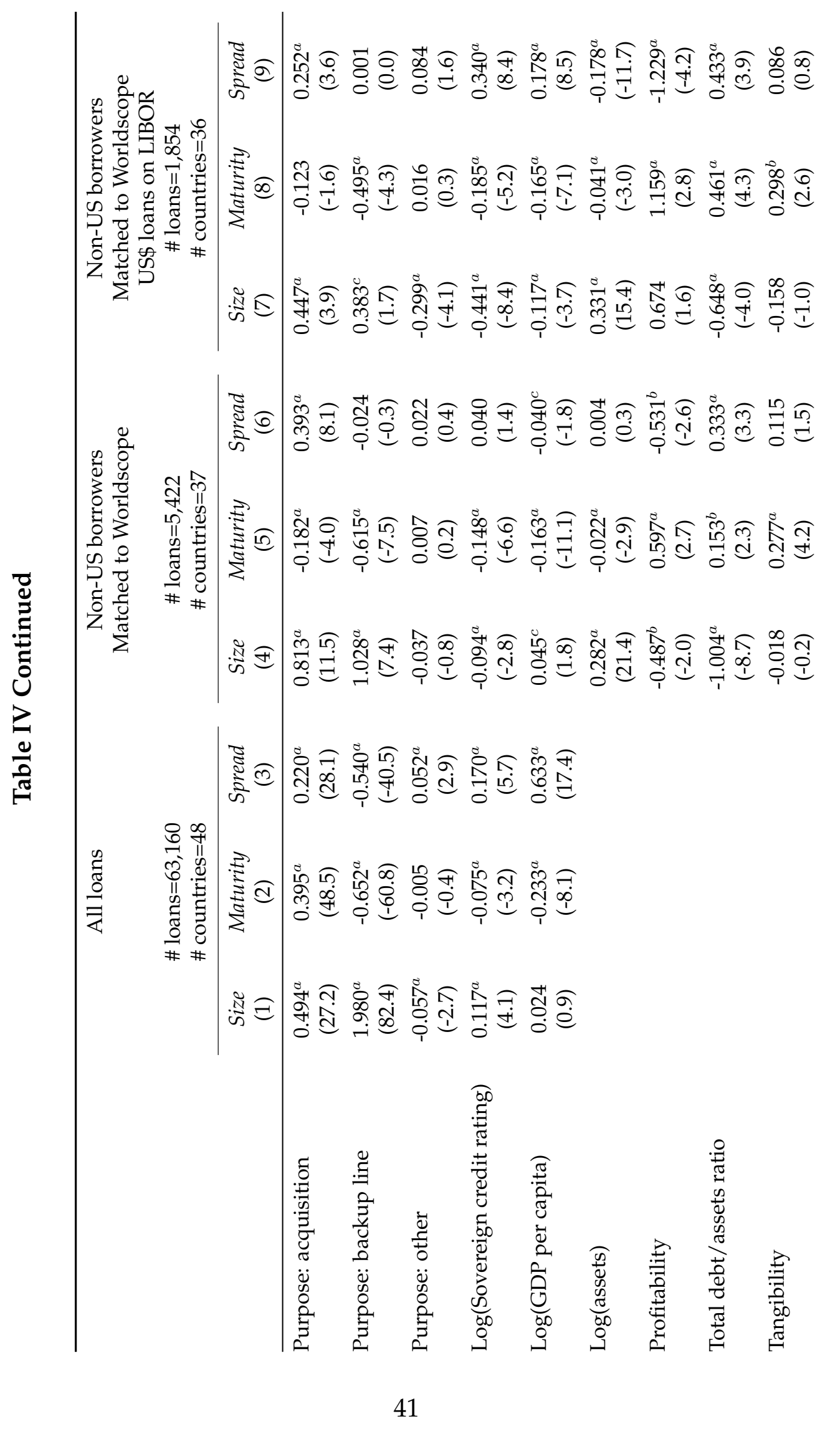




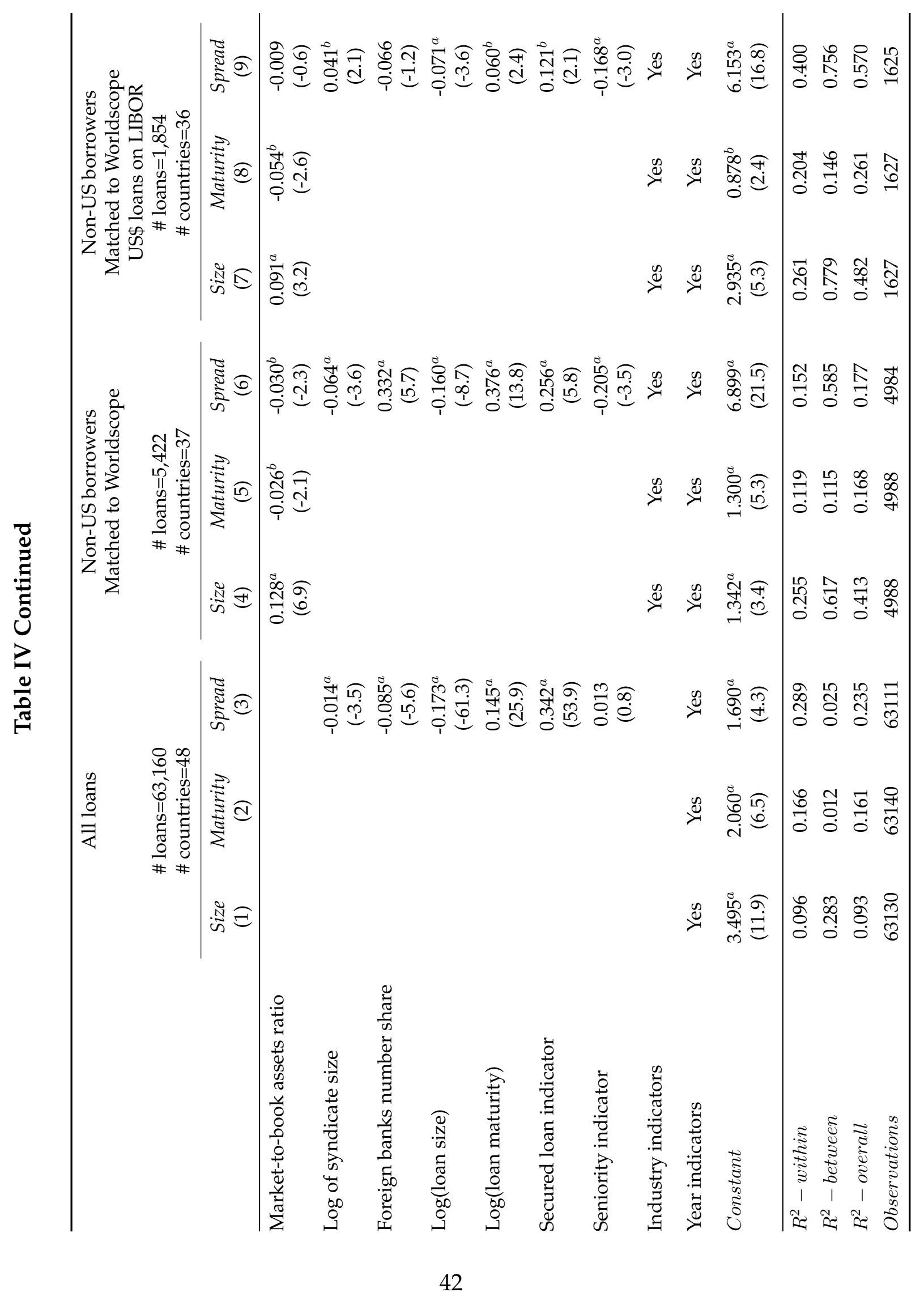




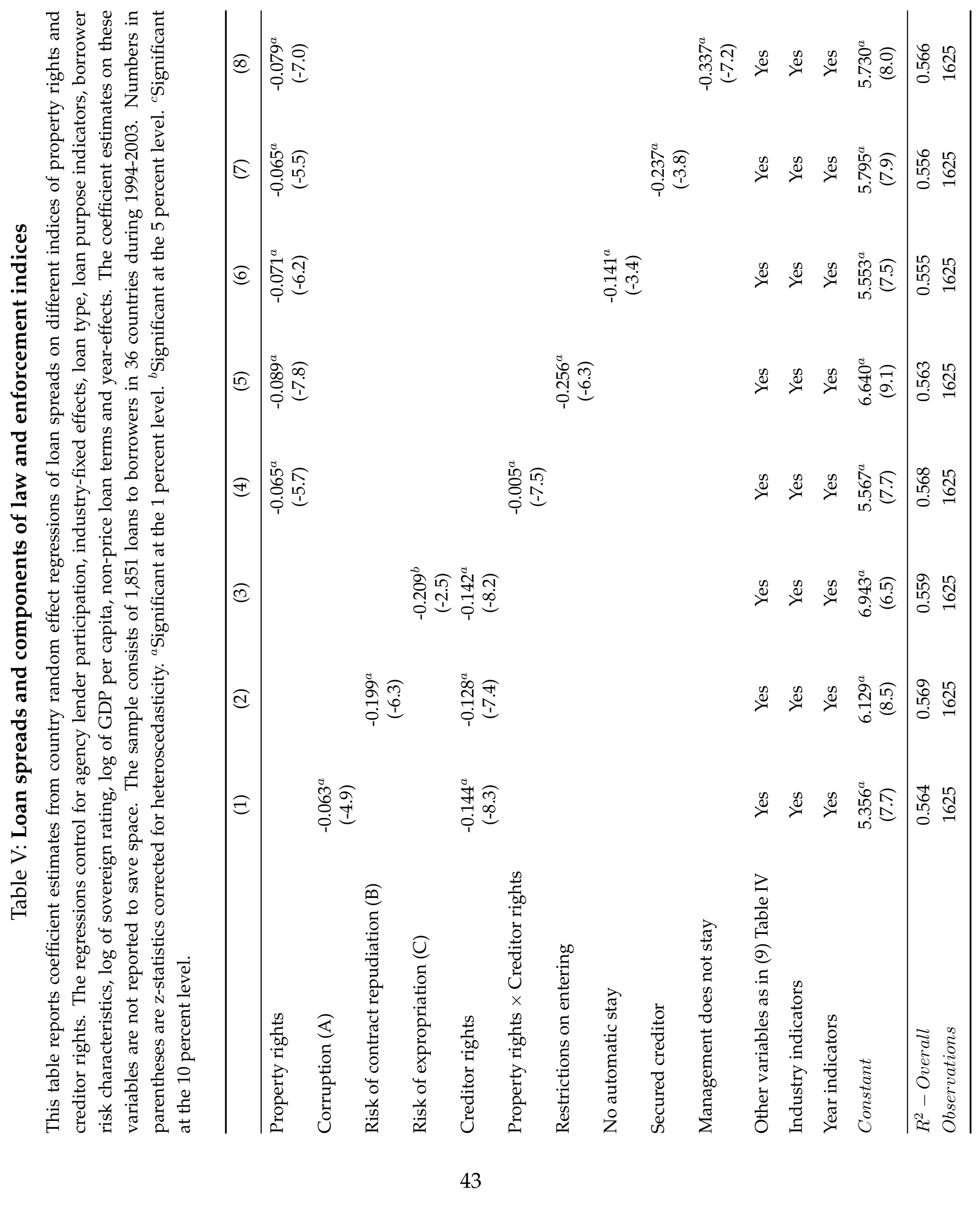




\section{Table VI \\ Alternative proxies for property rights}

This table reports coefficient estimates from country random effect regressions of loan spreads on creditor rights and alternative proxies of property rights. The alternative proxies considered are the (i) rule of law, (ii) efficiency of judicial system, (iii) index of economic freedom, (iv) enforcement, (v) property rights index from Knack and Keefer (1995), and (vi) enforcement time and enforcement cost. The regressions control for agency lender participation, industry-fixed effects, loan type, loan purpose indicators, borrower risk characteristics, log of sovereign rating, log of GDP per capita, non-price loan terms and year-effects. The coefficient estimates on these controls are not reported to save space. The sample consists of 1,851 loans to borrowers in 36 countries during 1994-2003. Numbers in parentheses are z-statistics corrected for heteroscedasticity. ${ }^{a}$ Significant at the 1 percent level. ${ }^{b}$ Significant at the 5 percent level. ${ }^{c}$ Significant at the 10 percent level.

\begin{tabular}{|c|c|c|c|c|c|c|}
\hline & (1) & (2) & (3) & (4) & (5) & (6) \\
\hline Rule of law & $\begin{array}{c}-0.087^{a} \\
(-4.5)\end{array}$ & & & & & \\
\hline Efficiency of judicial system & & $\begin{array}{c}-0.068^{a} \\
(-5.6)\end{array}$ & & & & \\
\hline Property rights (econ freedom) & & & $\begin{array}{c}-0.003 \\
(-0.1)\end{array}$ & & & \\
\hline Enforcement & & & & $\begin{array}{c}-0.179^{a} \\
(-6.2)\end{array}$ & & \\
\hline Property rights (Knack-Keefer) & & & & & $\begin{array}{c}-0.061^{a} \\
(-9.1)\end{array}$ & \\
\hline Enforcement time & & & & & & $\begin{array}{c}0.357^{a} \\
(7.1)\end{array}$ \\
\hline Enforcement cost & & & & & & $\begin{array}{c}0.128^{b} \\
(2.2)\end{array}$ \\
\hline Creditor rights & $\begin{array}{c}-0.127^{a} \\
(-7.2)\end{array}$ & $\begin{array}{c}-0.123^{a} \\
(-7.0)\end{array}$ & $\begin{array}{c}-0.144^{a} \\
(-7.8)\end{array}$ & $\begin{array}{c}-0.134^{a} \\
(-6.9)\end{array}$ & $\begin{array}{c}-0.131^{a} \\
(-7.7)\end{array}$ & $\begin{array}{c}-0.167^{a} \\
(-9.0)\end{array}$ \\
\hline Other variables as in (9) of Table IV & Yes & Yes & Yes & Yes & Yes & Yes \\
\hline Industry indicators & Yes & Yes & Yes & Yes & Yes & Yes \\
\hline Year indicators & Yes & Yes & Yes & Yes & Yes & Yes \\
\hline Constant & $\begin{array}{c}5.262^{a} \\
(7.5)\end{array}$ & $\begin{array}{c}4.719^{a} \\
(6.9)\end{array}$ & $\begin{array}{c}5.721^{a} \\
(8.4)\end{array}$ & $\begin{array}{c}4.387^{a} \\
(6.2)\end{array}$ & $\begin{array}{c}6.392^{a} \\
(8.8)\end{array}$ & $\begin{array}{c}1.736^{b} \\
(2.2)\end{array}$ \\
\hline$R^{2}-$ Overall & 0.563 & 0.566 & 0.567 & 0.577 & 0.580 & 0.603 \\
\hline Observations & 1625 & 1625 & 1590 & 1464 & 1625 & 1332 \\
\hline
\end{tabular}




\section{Table VII \\ Additional macroeconomic controls}

This table presents coefficients from country random effects regressions of loan spreads on property rights index and creditor index with additional macroeconomic variables as controls. These are (i) GDP growth volatility, (ii) the liquid liabilities/GDP ratio, (iii) the stock market traded value/GDP ratio, and (iv) credit to private sector/ GDP ratio. The regressions control for agency lender participation, industry-fixed effects, loan type, loan purpose indicators, borrower risk characteristics, log of sovereign rating, log of GDP per capita, non-price loan terms and year-effects. The coefficient estimates on these controls are not reported to save space. The sample consists of 1,851 loans to borrowers in 36 countries during 1994-2003. Numbers in parentheses are z-statistics corrected for heteroscedasticity. ${ }^{a}$ Significant at the 1 percent level. ${ }^{b}$ Significant at the 5 percent level. ${ }^{c}$ Significant at the 10 percent level.

\begin{tabular}{lcccc}
\hline & $(1)$ & $(2)$ & $(3)$ & $(4)$ \\
\hline Property rights & $-0.080^{a}$ & $-0.102^{a}$ & $-0.078^{a}$ & $-0.076^{a}$ \\
& $(-6.8)$ & $(-7.1)$ & $(-6.8)$ & $(-5.9)$ \\
Creditor rights & $-0.155^{a}$ & $-0.229^{a}$ & $-0.175^{a}$ & $-0.141^{a}$ \\
& $(-8.9)$ & $(-8.4)$ & $(-9.0)$ & $(-6.6)$ \\
GDP growth volatility & $0.005^{a}$ & & & \\
Liquid liabilities/GDP & $(5.7)$ & & & \\
Stock market traded value/GDP & & $-0.002^{a}$ & & \\
Credit to private sector & & $(-2.9)$ & & \\
& & & & \\
Other variables as in (9) of Table IV & Yes & Yes & Yes & Yes \\
Industry indicators & Yes & Yes & Yes & Yes \\
Year indicators & Yes & Yes & Yes & Yes \\
Constant & $6.637^{a}$ & $7.429^{a}$ & $5.946^{a}$ & $6.263^{a}$ \\
& $(9.3)$ & $(9.8)$ & $(8.1)$ & $(8.5)$ \\
\hline$R^{2}-$ Overall & 0.579 & 0.608 & 0.577 & 0.576 \\
Observations & 1519 & 1328 & 1597 & 1583 \\
\hline
\end{tabular}




\section{Table VIII}

\section{Loan sizes, maturity and spreads around the East Asian crisis of 1997-98}

This table reports coefficient estimates from country random effect regressions of loan sizes, loan maturities, and loan spreads on property rights, creditor rights, and the following interaction terms: (i) property rights $\times$ East Asian crisis period indicator, (ii) creditor rights $\times$ East Asian crisis period indicator, and (iii) East Asia region indicator $\times$ crisis period indicator. The East Asian region indicator takes a value of one if the borrower is from one of the following countries: Hong Kong, Indonesia, Korea, Malaysia, Philippines, Singapore, Thailand, and Taiwan. Is is otherwise set equal to zero. The crisis period indicator is one if the loan was offered during July 1, 1997 and August 31, 1998, the crisis period. It is otherwise set equal to zero. The regressions control for agency lender participation, industry-fixed effects, loan type, loan purpose indicators, borrower risk characteristics, log of sovereign rating, log of GDP per capita, non-price loan terms and year-effects. The coefficient estimates on these variables are not reported to save space. The sample consists of 1,851 loans to borrowers in 36 countries during 1994-2003. Numbers in parentheses are z-statistics corrected for heteroscedasticity. ${ }^{a}$ Significant at the 1 percent level. ${ }^{b}$ Significant at the 5 percent level. ${ }^{c}$ Significant at the 10 percent level.

\begin{tabular}{|c|c|c|c|c|c|c|}
\hline & \multicolumn{2}{|c|}{ Size } & \multicolumn{2}{|c|}{ Maturity } & \multicolumn{2}{|c|}{ Spread } \\
\hline & (1) & (2) & (3) & (4) & (5) & (6) \\
\hline Property rights & $\begin{array}{c}0.088^{a} \\
(7.2)\end{array}$ & $\begin{array}{c}0.089^{a} \\
(7.3)\end{array}$ & $\begin{array}{c}0.075^{a} \\
(8.1)\end{array}$ & $\begin{array}{c}0.076^{a} \\
(8.2)\end{array}$ & $\begin{array}{r}-0.095^{a} \\
(-10.7)\end{array}$ & $\begin{array}{c}-0.114^{a} \\
(-13.6)\end{array}$ \\
\hline Creditor rights & $\begin{array}{c}-0.025 \\
(-1.0)\end{array}$ & $\begin{array}{c}-0.023 \\
(-1.0)\end{array}$ & $\begin{array}{c}-0.005 \\
(-0.3)\end{array}$ & $\begin{array}{c}-0.008 \\
(-0.4)\end{array}$ & $\begin{array}{c}-0.148^{a} \\
(-8.7)\end{array}$ & $\begin{array}{c}-0.131^{a} \\
(-7.6)\end{array}$ \\
\hline East Asia $\times$ Crisis & $\begin{array}{c}-0.213 \\
(-1.5)\end{array}$ & $\begin{array}{c}-0.082 \\
(-0.5)\end{array}$ & $\begin{array}{c}-0.216^{b} \\
(-2.0)\end{array}$ & $\begin{array}{c}-0.234^{b} \\
(-2.0)\end{array}$ & $\begin{array}{c}0.419^{a} \\
(4.3)\end{array}$ & $\begin{array}{c}0.420^{a} \\
(3.9)^{\prime}\end{array}$ \\
\hline Property rights $\times$ Crisis & $\begin{array}{c}0.003 \\
(0.8)\end{array}$ & & $\begin{array}{c}0.003 \\
(0.9)\end{array}$ & & $\begin{array}{c}-0.012^{a} \\
(-3.9)\end{array}$ & \\
\hline Creditor rights $\times$ Crisis & & $\begin{array}{r}-0.037 \\
(-0.9)\end{array}$ & & $\begin{array}{c}0.030 \\
(1.0)\end{array}$ & & $\begin{array}{c}-0.063^{b} \\
(-2.2)\end{array}$ \\
\hline Other variables as in (7)-(9) of Table IV & Yes & Yes & Yes & Yes & Yes & Yes \\
\hline Industry indicators & Yes & Yes & Yes & Yes & Yes & Yes \\
\hline Year indicators & Yes & Yes & Yes & Yes & Yes & Yes \\
\hline Constant & $\begin{array}{c}-0.204 \\
(-0.2)\end{array}$ & $\begin{array}{c}-1.132 \\
(-1.1)\end{array}$ & $\begin{array}{c}-0.558 \\
(-0.7)\end{array}$ & $\begin{array}{c}-0.562 \\
(-0.7)\end{array}$ & $\begin{array}{r}8.850^{a} \\
(12.9)\end{array}$ & $\begin{array}{r}9.078^{a} \\
(12.9)\end{array}$ \\
\hline$R^{2}-$ Overall & 0.571 & 0.246 & 0.543 & 0.573 & 0.246 & 0.543 \\
\hline Observations & 1627 & 1627 & 1625 & 1627 & 1627 & 1625 \\
\hline
\end{tabular}




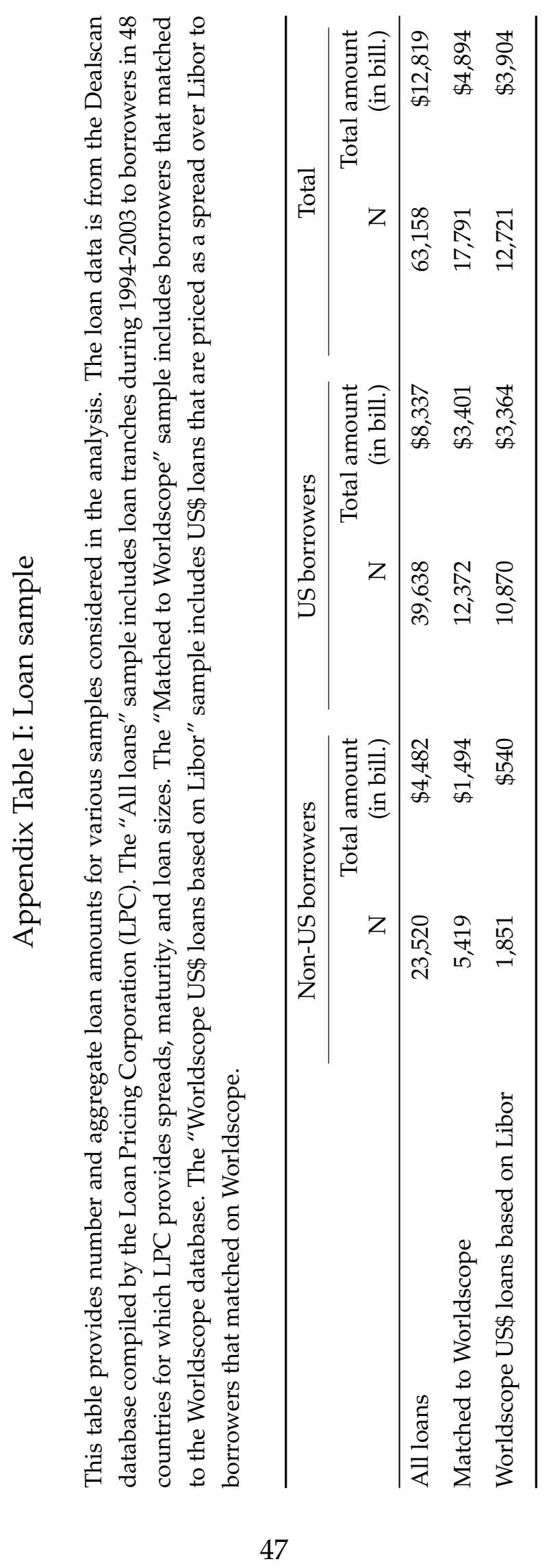




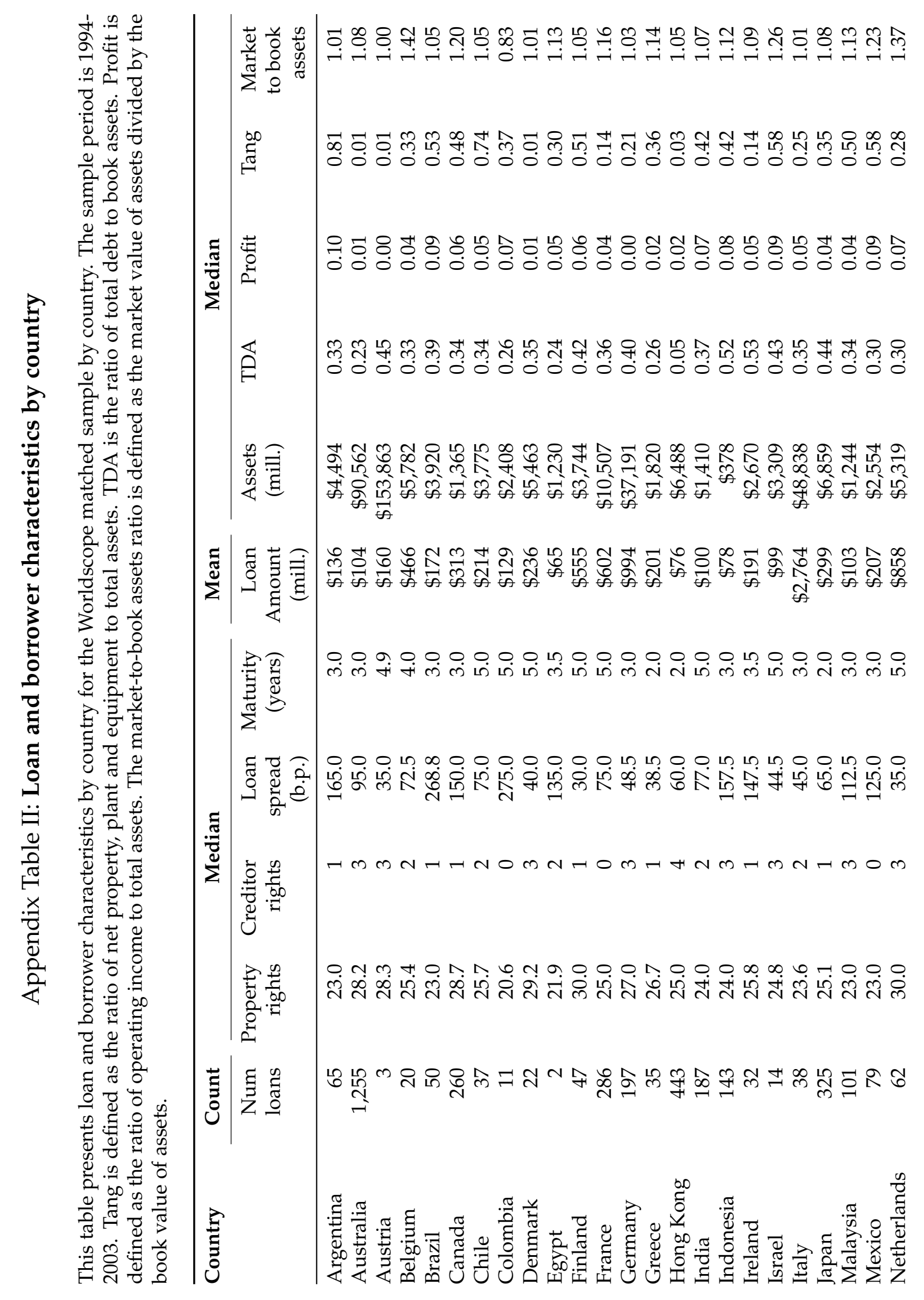




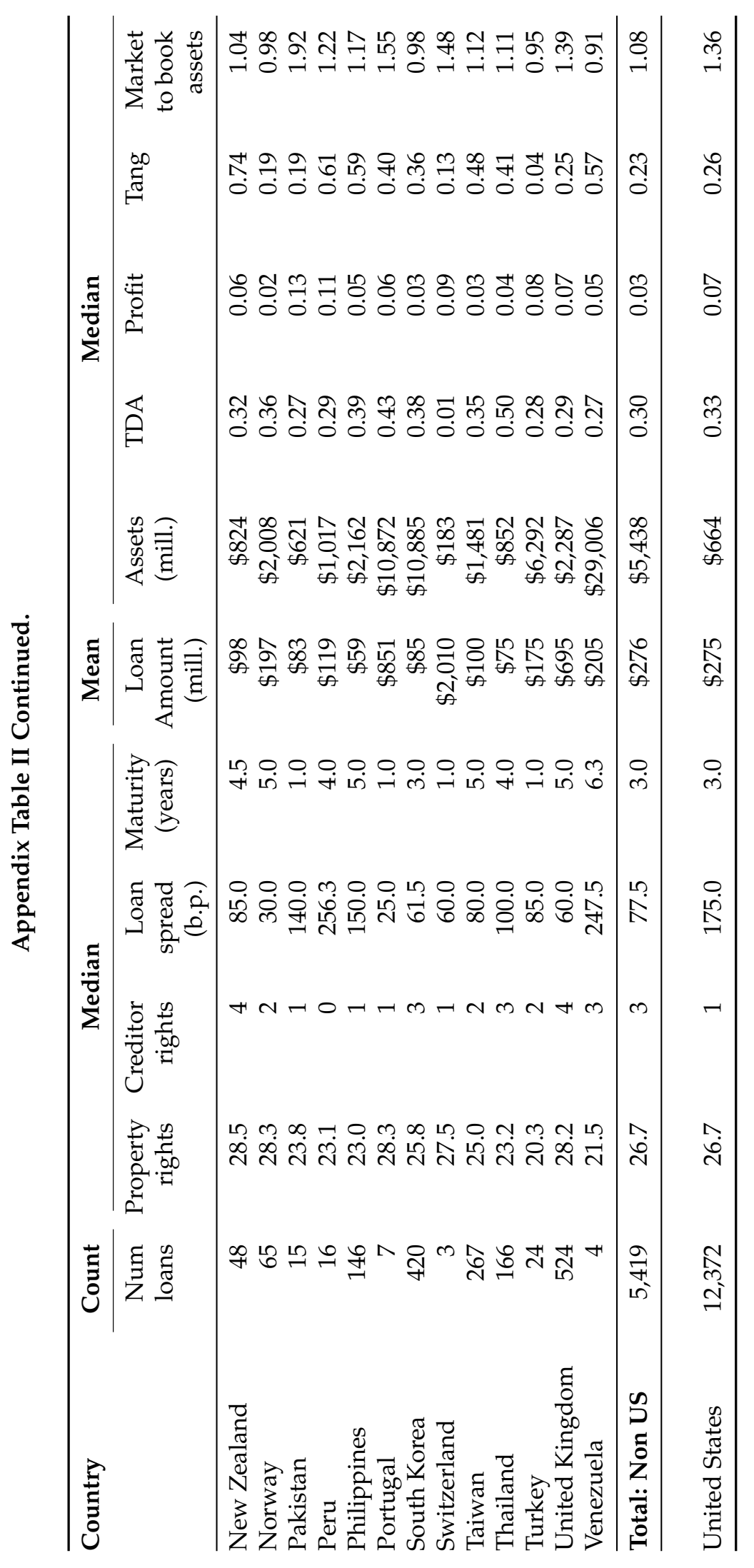




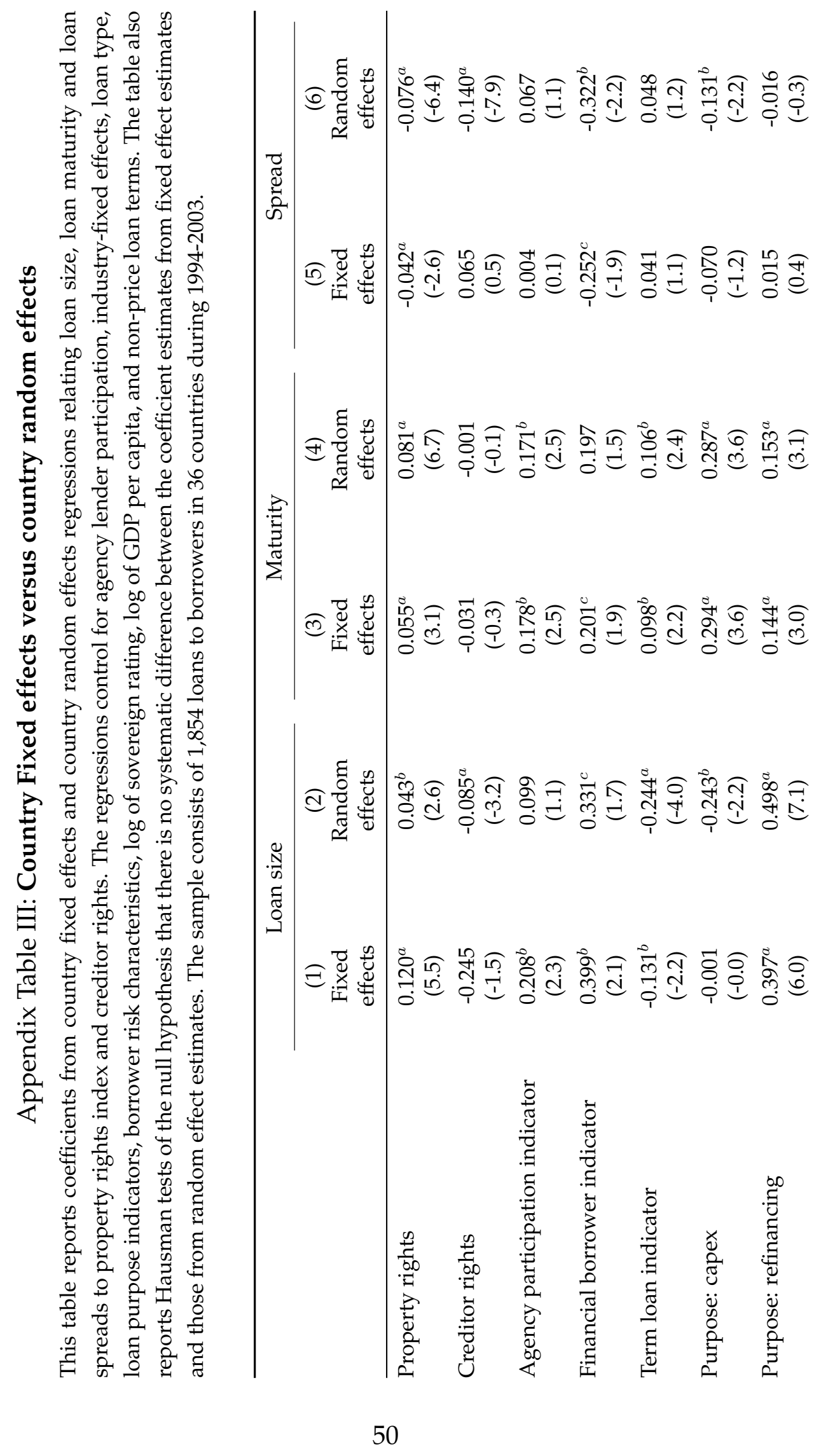




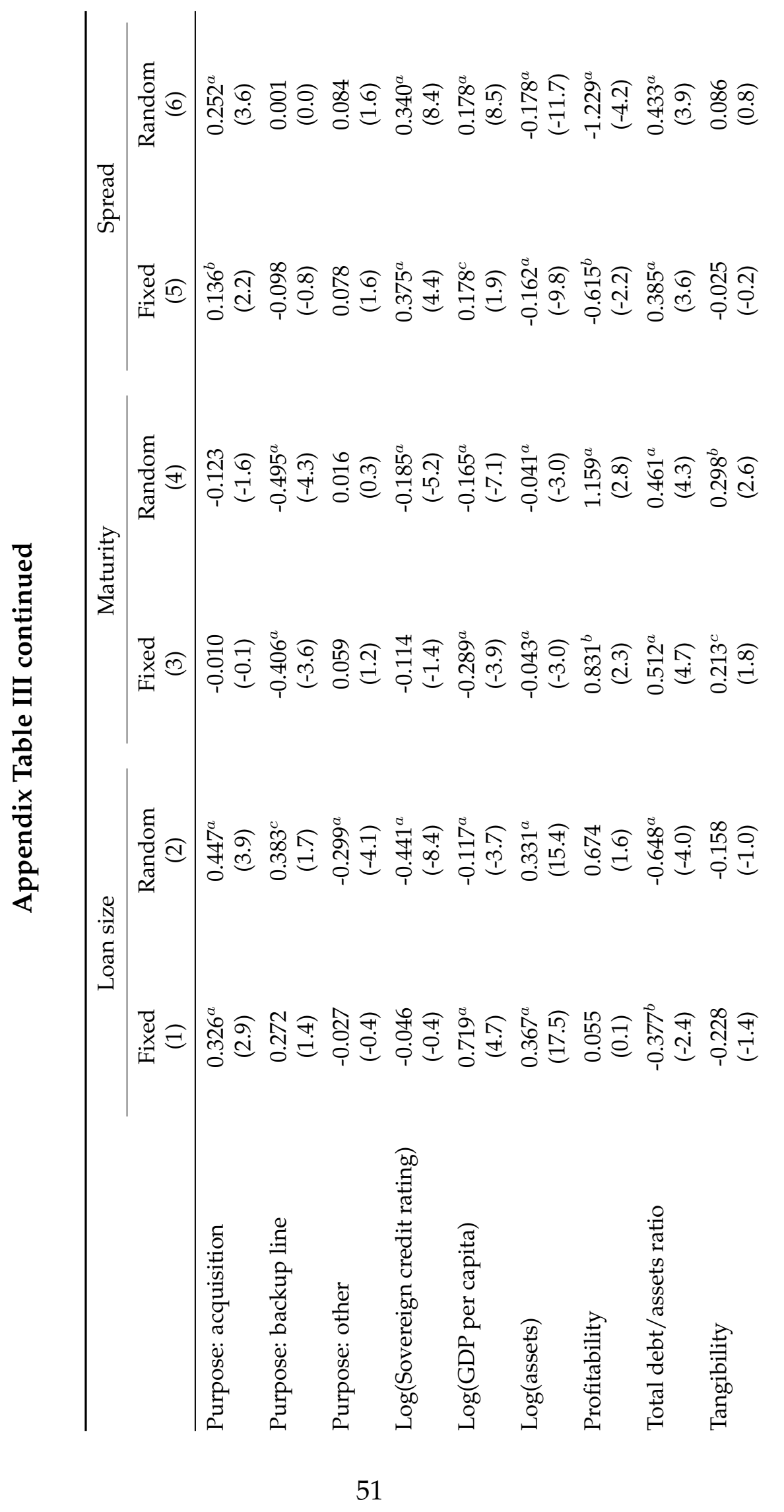




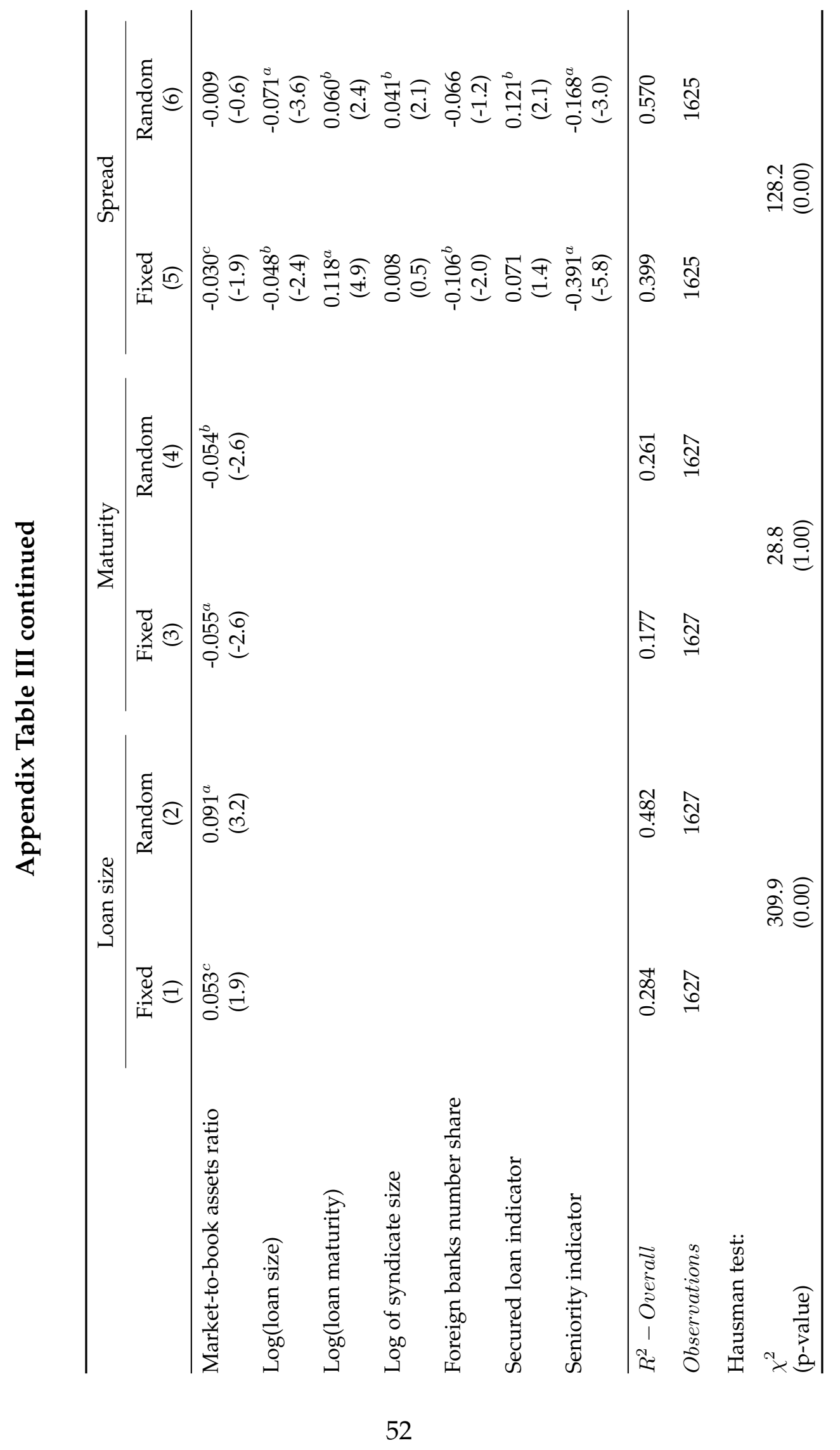

